\title{
Development and characterization of cold- adapted viruses for use as live virus vaccines
}

\author{
H.F. Maassab and Dan C. DeBorde
}

Representative viruses from twelve RNA and two DNA virus genera have been successfully adapted to growth at sub-optimal temperature (cold-adapted). In almost every case, there was a correlation between acquisition of the cold-adaptation phenotype and loss of virulence in the normal host whether animal or man. Overall, the best method of cold adaptation to develop a live virus vaccine line appeared to be a stepwise lowering of the growth temperature allowing time for multiple lesions to occur and/or be selected. In addition, the starting virus should be a recent isolate not as yet adapted to a tissue culture host and the cold-adaptation process should then occur in a host heterologous to the virus' normal host. These viruses have been reviewed in the light of their coldadaptation method and successful production of an attenuated line as virus vaccine candidate. Finally, detailed information is presented for the cold-adaptation process in influenza virus.

Keywords: Viruses; cold adaptation; live virus vaccines

\section{Introduction}

Virulence of a virus, a variable characteristic under polygenic control is influenced by the virus strain. the host or both these things. A review of the literature provides numerous examples of factors modifying virulence, some classified as host factors. while others are considered as viral in origin. In the interactions of the virus with its host cell, both entities play an important role in the determination of the outcome which is a measure of the virulence of the virus. The host factors affecting manifestation of virulence and also influencing the outcome of host-virus interactions are determined by the genetic constitution and also the physiologic state of the host cells. Systemic factors both specific such as immunity of the host as well as non-specific, such as hormones,

Department of Epidemiology, School of Public Health, The University of Michigan, Ann Arbor, Michigan 48109, USA nutrition and age can also influence the consequences of exposing a host to virus. The properties of a virus that are important determinants of virulence are: quality, e.g inactive or defective virus competes for cell receptor in the initiation of infection, the quantity or the dose of the virus and its genetic constitution. The mechanisms in the expression of virulence are also influenced by viruses that are poor inducers of interferon and those which tend to be resistant to interferon by their ability to spread and to exhibit a high rate of multiplication in the host cell. An additional property that also affects the course of infection is host temperature. In vivo observations have demonstrated that high temperature plays a defensive role and can suppress viral replication and limit spread whilst lower temperature allows a higher rate of viral replication and more severe expression of a disease.

The role of temperature in microbial disease has been the subject of numerous reports in the literature, a high normal body temperature in certain species of animals being found to play a defensive role in immunity to infection'. Enders and Shaffer ${ }^{2}$ presented definitive evidence that the capacity of Pneumococcus III to multiply at $41^{\circ} \mathrm{C}$ was a genetic property and thus gave the first hint of the effect of temperatures on virulence of different strains of the same microbe. In general, it was stated that hyperthermia has no effect on highly virulent strains, whereas it has a marked effect on strains with low virulence. Burnet in 1936 demonstrated that an animal virus such as influenza produced lesions and death of eggs incubated at $36^{\circ} \mathrm{C}$ but not at $39^{\circ} \mathrm{C}$. The studies in animals, although qualitative and sometimes speculative in nature, have not offered any more insight into the mode of action: it is not clear whether the mechanism involves changes in the host or whether it affects the virus directly.

In vitro studies have shown that temperature alters viral development in tissue culture infected cells. Correlation was found between virulence and the ability of virulent strains to grow at temperatures above physiological range $\left(\simeq 40^{\circ} \mathrm{C}\right)$. From all points of view, virulence can be quantified and it is a quality that can be added to or lost experimentally from a virus strain.

In recent years, emphasis has been placed on development of techniques for quantification of the events 
that underlie the basis of virulence and on attempts to define molecular aspects of virus replication. One approach has been the development of thermo-sensitive lines of virus using chemical mutagens. Temperature sensitive mutants (ts) have permitted, in some instances, the definition of the number of genes in virus genomes and their function. The acquisition of ts lesions apparently caused a decrease in virulence. In the field of practical virology, the isolation of these mutants has provided the opportunity for their use as attenuated live vaccine strains. The development and use of conditionallethal mutants of animal viruses has been the subject of two elegant reviews by Fenner ${ }^{4}$ and more recently by Ghendon

\section{Characterization of cold-adapted mammalia viruses}

In general, cold adaptation requires serial or step-wise passages at reduced temperatures for the derivation of

Table 1 Cold-adapted mutants of animal viruses

\begin{tabular}{|c|c|c|}
\hline Virus & Method of cold-adaptation & Reference \\
\hline \multicolumn{3}{|l|}{$\begin{array}{l}\text { RNA viruses } \\
\text { Genus Alphavirus }\end{array}$} \\
\hline Sindbis & Passage at $25^{\circ} \mathrm{C}$ & Kitsak ${ }^{66}$ \\
\hline \multicolumn{3}{|l|}{ Genus Flavivirus } \\
\hline $\begin{array}{l}\text { Japanese B } \\
\text { encephalitis }\end{array}$ & $\begin{array}{l}\text { Stepwise passage at } 35^{\circ} \mathrm{C}(5), 33^{\circ} \mathrm{C}(5) \text {, } \\
30^{\circ} \mathrm{C}(5), 27^{\circ} \mathrm{C}(5) \text {, and } 24^{\circ} \mathrm{C}(5)\end{array}$ & Rohitayodhin ${ }^{13,67}$ and Hammon \\
\hline Japanese encephalitis & $\begin{array}{l}\text { Stepwise passage at } 33^{\circ} \mathrm{C}(9), 30^{\circ} \mathrm{C}(9) \text {, } \\
27^{\circ} \mathrm{C}(8), 25^{\circ} \mathrm{C}(21)\end{array}$ & Yoshida et al. ${ }^{14}$ \\
\hline \multicolumn{3}{|l|}{ Genus Aphthovirus } \\
\hline Foot and mouth disease & Passage at low temperatures & Wittman and $\mathrm{AhI}^{70}$ \\
\hline Foot and mouth disease & Passage at $37^{\circ} \mathrm{C}$ and $24^{\circ} \mathrm{C}$ & Urvantesev et al. ${ }^{71}$ \\
\hline \multicolumn{3}{|l|}{ Genus Enterovirus } \\
\hline Polio & Passage at $30^{\circ} \mathrm{C}(13)$ & Dubes and Chapin 6 \\
\hline Polio & $\begin{array}{l}\text { Passage at } 23^{\circ} \mathrm{C}(15) \text { of the adapted } \\
\text { virus, above }\end{array}$ & Dubes and Wenner ${ }^{7}$ \\
\hline Polio & Stepwise passage at $25^{\circ} \mathrm{C}(10), 23^{\circ} \mathrm{C}(5)$ & Koprowski et al. ${ }^{9}$ \\
\hline Polio & Stepwise passage at $30^{\circ} \mathrm{C}, 27^{\circ} \mathrm{C}$, and $25^{\circ} \mathrm{C}$ & Lwoff 8 \\
\hline Polio & $\begin{array}{l}\text { Stepwise passage at } 33^{\circ} \mathrm{C}(7), 30^{\circ} \mathrm{C}(10) \text {, } \\
\text { and } 25^{\circ} \mathrm{C}(20)\end{array}$ & Sabin' \\
\hline Coxsackie B5 & $\begin{array}{l}\text { Stepwise passage at } 35^{\circ} \mathrm{C}(5), 30^{\circ} \mathrm{C}(3) \text {, } \\
28^{\circ} \mathrm{C}(3), 26^{\circ} \mathrm{C}(18)\end{array}$ & Gevaudan et al. ${ }^{12}$ \\
\hline Echo 9 & Passage at $30^{\circ} \mathrm{C}(25)$ & Jablonski ${ }^{11}$ \\
\hline \multicolumn{3}{|l|}{ Genus Arenavirus } \\
\hline $\begin{array}{l}\text { Lymphocytic } \\
\text { choriomeningitis }\end{array}$ & Passage at $25^{\circ} \mathrm{C}(17)$ & Brayton and Maassab ${ }^{15}$ \\
\hline \multicolumn{3}{|l|}{ Genus Orbivirus } \\
\hline African horse sickness & Stepwise passage at low temperatures & Mirchamsky and Taslimi ${ }^{72}$ \\
\hline \multicolumn{3}{|l|}{ Genus Orthomyxovirus } \\
\hline Influenza type A & Passage at $26-28^{\circ} \mathrm{C}(45)$ & Aleksandrova 28.78 and Smorodintsev ${ }^{29}$ \\
\hline Influenza type A & $\begin{array}{l}\text { Stepwise passage at } 36^{\circ} \mathrm{C}(60), 33^{\circ} \mathrm{C}(10) \text {, } \\
30^{\circ} \mathrm{C}(10), 27^{\circ} \mathrm{C}(10), 25^{\circ} \mathrm{C}(10)\end{array}$ & Maassab 30 \\
\hline Influenza type B & $\begin{array}{l}\text { Stepwise passage at } 33^{\circ} \mathrm{C}(1), 30^{\circ} \mathrm{C}(4) \\
27^{\circ} \mathrm{C}(2), 25^{\circ} \mathrm{C}(2)\end{array}$ & Maassab $^{73}$ \\
\hline \multicolumn{3}{|l|}{ Genus Morbillivirus } \\
\hline Measles & Stepwise passage to $33-25^{\circ} \mathrm{C}$ & Hozinski et al. ${ }^{74}$ \\
\hline \multicolumn{3}{|l|}{ Genus Paramyxovirus } \\
\hline Parainfluenza type 1 & Passage at $26^{\circ} \mathrm{C}(20)$ & Potash et al. ${ }^{16}$ \\
\hline Parainfluenza type 1 & Passage at $25^{\circ} \mathrm{C}$ & Maassab, unpublished data \\
\hline Parainfluenza type 3 & $\begin{array}{l}\text { Stepwise passage at } 33.5^{\circ} \mathrm{C}(3), 22^{\circ} \mathrm{C}(10) \text {, } \\
20^{\circ} \mathrm{C}(35)\end{array}$ & Belshe and Hisson ${ }^{18}$ \\
\hline \multicolumn{3}{|l|}{ Genus Pneumovirus } \\
\hline $\begin{array}{l}\text { Respiratory syncytial } \\
\text { virus }\end{array}$ & $\begin{array}{l}\text { Stepwise passage at } 34^{\circ} \mathrm{C}(21), \\
28^{\circ} \mathrm{C}(12), 26^{\circ} \mathrm{C}(19)\end{array}$ & Friedewald et al. ${ }^{19}$ \\
\hline $\begin{array}{l}\text { Respiratory syncytial } \\
\text { virus }\end{array}$ & Passage at $25^{\circ} \mathrm{C}$ & Maassab, unpublished data \\
\hline $\begin{array}{l}\text { virus } \\
\text { Genus Reovirus }\end{array}$ & & \\
\hline \multicolumn{2}{|l|}{ Genus Reovirus } & \\
\hline & van der Heide ${ }^{75}$ \\
\hline Rabies & Passage at low temperature & \\
\hline Rabies & Passage at $23^{\circ} \mathrm{C}$ & Clark and Witkor ${ }^{21}$ \\
\hline Vesicular stomatitis & Passage at $30^{\circ} \mathrm{C}(9)$ & Flamand $^{23}$ \\
\hline \multicolumn{3}{|l|}{ DNA Viruses } \\
\hline Adenoviruses & Passage at low temperatures & Yurlova et al. ${ }^{76}$ \\
\hline $\begin{array}{l}\text { Herpes simplex } \\
\text { types } 1 \text { and } 2\end{array}$ & Passage at $25^{\circ} \mathrm{C}(10)$ & Maassab and McFarland ${ }^{24}$ Huang et al. ${ }^{25}$ \\
\hline \multicolumn{3}{|l|}{ Genus Poxvirus } \\
\hline Vaccinia & Passage at $30^{\circ} \mathrm{C}, 22^{\circ} \mathrm{C}$ & Fidzianska ${ }^{77}$ \\
\hline Vaccinia & $\begin{array}{l}\text { Stepwise passage at } 30^{\circ} \mathrm{C}(10), 29^{\circ} \mathrm{C}(4) \text {, } \\
27^{\circ} \mathrm{C}(1), 125^{\circ} \mathrm{C}(5)\end{array}$ & Kirn and Braunwald 26 \\
\hline
\end{tabular}


attenuated cold variants containing multiple lesions in their genomes. Cold adaptation of animal viruses is generally accompanied by loss of virulence and the appearance of various distinctive markers which may vary with the virus and host system. The biological attributes that are generally acquired by viruses when adapted to grow at low temperatures are reduction of virulence and reduced plaquing efficiency at high temperatures. These markers, plus various others which are more variable in occurrence (restriction of growth in certain host cells, temperature stability, sensitivity to low $\mathrm{pH}$, and plaque size) can be used to differentiate the coldadapted strains from their progenitors. Table 1 represents a summary of the cold-adapted animal viruses that have been produced and the procedure followed for their development.

The attenuation of animal viruses for use as live vaccines has been achieved by: (1) serial passage of virus in heterologous hosts; (2) repeated serial passages in a single host; and (3) adaptation of the virus to grow at suboptimal temperature ${ }^{1}$.

Adaptation of viruses to grow at lower temperatures (usually $25^{\circ} \mathrm{C}$ ) using diverse techniques will be the central theme of this section for development and characterization of live attenuated virus vaccines intended for human use. The following aspects of cold adaptation of animal viruses will be considered: (1) the procedure and criteria used to select adapted strains; (2) quantification and characterization of the cold adapted strains; (3) methods used to evaluate in vitro and in vivo loss of virulence; (4) presence of markers; (5) genetic stability and (6) behaviour and acceptability as live virus vaccine candidates. Studies of cold-adapted animal viruses other than influenza viruses, and studies of attenuation of influenza virus by cold adaptation for use as live virus vaccines in man will be covered. For some of the early work on animal viruses listed in Table 1 detailed biological analysis with quantitative data are not available. This section will include summary data only for those viruses which have a sufficient body of information to allow interpretation of the relationship between cold adaptation and loss of virulence.

\section{Enterovirus}

Early work on cold adaptation was performed on the three types of poliovirus at $23-30^{\circ} \mathrm{C}$ by several groups ${ }^{1,6-10}$. These groups were able to demonstrate that gradual lowering of the temperature during serial propagation of the viruses resulted in the derivation of cold mutants, showing increased reproductive capacity of growth at low temperature $\left(\mathrm{rct} / 25^{\circ} \mathrm{C}+\right)$ and decreased infectivity at higher temperatures $\left(\mathrm{rct} / 40^{\circ} \mathrm{C}-\right.$ ). The cold mutants were less virulent when inoculated intraspinally in rhesus and cynomulgus monkeys. Characteristics of those cold mutants included small plaque size at higher temperatures and larger plaque size at lower temperatures. Sensitivity to low bicarbonate or low $\mathrm{pH}$ resulted in lower plating efficiency. Variation did not exist in growth properties within the set of cold mutants or within the set of their progenitors upon growth at differing temperatures and also in the degree of attenuation to the subhuman primates. For high yielding cold mutants of three types of polio, plaque-purification was accomplished and genetic stability demonstrated and attenuation documented for their use as live virus vaccines.

A cold mutant of Echo 9 was developed by Jablonski ${ }^{11}$ through passages of lower temperature 25 or $30^{\circ} \mathrm{C}$. Lowering the temperature of incubation of infected cells resulted in the derivation of a mutant with altered biological properties. The mutant exhibited the rct/40-(T marker) characteristic and also slight antigenic changes when compared to the prototype strain. The kinetics of growth at different temperatures was host-dependent, with variations in infectious titres apparent between the strains. Since the original viral preparation was not cloned, a conclusion concerning whether selection or spontaneous mutation can explain the emergence of the mutant is not possible. Data on the alteration of virulence of the mutant during adaptation were not furnished.

A third virus of the Picornaviridae family, coxsackie B5, was adapted to growth at low temperature ${ }^{12}$. A cloned preparation of coxsackie $\mathrm{B} 5$ has undergone progressive adaptation to lower temperatures starting with a $36^{\circ} \mathrm{C}$ incubation and ending with a $26^{\circ} \mathrm{C}$ incubation. The 'cold' mutant was plaque-purified at $26^{\circ} \mathrm{C}$ prior to characterization in vitro and in vivo. Comparison of the cold variant to the original strain has shown the acquisition of the temperature-sensitive marker in the cold' line. Decreased virulence to suckling mice of the cold-adapted strain upon intracerebral inoculation was also shown. Thus, adaptation of coxsackie B5 to growth at low temperature was correlated with attenuation.

\section{Flavivirus}

Attenuated strains of Japanese encephalitis (JE) virus have been produced through cold adaptation by two different laboratories. Rohitayodhin and Hammon ${ }^{13}$ tried to attenuate two different strains of Japanese $B$ encephalitis (JBE) virus by adaptation to growth in hamster kidney cell (HKC) tissue culture at suboptimal temperatures. One strain was the mouse-adapted Nakayama virus in its 47 th mouse passage. The other was a mosquito isolate designated Okayama Culex tritaeniorhynchus-541 (OCT-541). The Nakayama virus failed to show any significant change in mouse virulence, which the authors intepreted to mean that its extensive growth in mice had removed any mouse-attenuated virus particles prior to their own selection procedures. OCT-541, however, did show a significant change in mouse virulence when administered subcutaneously (s.c.). This virus was cold adapted by several different methods. Two lines were grown directly at the low temperatures of 27 and $24^{\circ} \mathrm{C}$, and two lines were stepwise adapted to a final temperature of $24^{\circ} \mathrm{C}$, one with one passage at each intermediate temperature and one with five passages at each intermediate temperature (see Table 1). All these lines showed a drop of one to two log units in $\mathrm{LD}_{50}$ titres when given intracerebrally (i.c.) in suckling mice, and the average survival times were seen to increase from 6 to 12 days. The virus adapted by five passages at each intermediate temperature (line 35-24) proved to possess the most stable attenuated characteristics, and was chosen as the virus to use in further experiments. Because this disease follows a mosquito-swine cycle, it was also desirable to test the attenuated virus in mosquitoes. Unlike the original unadapted OCT-541 strain, the coldadapted line 35-24 failed to infect the mosquitoes and no transmission could be demonstrated. The only problem with line 35-24 for use as a live virus vaccine is that the mice demonstrated no production of neutralizing antibody after being infected with the attenuated virus, and these mice showed no immunity to subsequent wild type virus challenge.

Later work ${ }^{\mathbf{1 4}}$ used a virus isolated from the brain of a $\mathrm{JE}$ patient who died in Osaka Prefecture in 1966. While these researchers also used a stepwise cold-adaptation method, 
their experiments were expanded in the number of markers examined at each stage of cold adaptation and the tissue culture system used was monkey kidney cells. Once a cold variant was achieved which had the desired attenuation and immunogenicity it was further adapted to growth at $33^{\circ} \mathrm{C}$ in quail embryo fibroblasts for better efficiency of virus growth for vaccine production. Virus lines were tested for virulence in $5 \mathrm{~g}$ mice and in suckling mice, both i.c. and s.c.; production of viraemia in one month old piglets; infection rate in CT mosquitoes; and finally neurovirulence in monkeys. After primary adaptation in monkey kidney cells at $37^{\circ} \mathrm{C}$ for 68 passages, the virus had already lost its capacity to cause viraemia in one month old piglets. This ability never returned. After adaptation to $33^{\circ} \mathrm{C}$ it could no longer cause disease in $5 \mathrm{~g}$ mice s.c., and finally over the course of 21 passages at $25^{\circ} \mathrm{C}$ the virus showed; (1) lower virulence on ic. injection into 5 g mice; (2) a higher i.c./s.c. ratio of $\mathrm{LD}_{50}$ titres in suckling mice; (3) very low infectivity in CT mosquitoes; and (4) no encephalitis upon i.c. injection into monkeys. All markers were retained after growth on quail embryo fibroblasts at $30^{\circ} \mathrm{C}$. In addition, all markers of attenuation remained stable after passage in suckling mouse brain or after infection in one day old chicks. Protection experiments in one week old or in one month old piglets showed no virus disease due to vaccine, and piglets were resistant to challenge with $8.5 \mathrm{logs}$ of infectious virus (100 times the maximal amount of virus contained in a whole mosquito). Pregnant sows given this live virus vaccine showed no disease and delivered normally. No vaccine virus was isolated from the new-born piglets. The use of multiple markers for screening and the stepwise method of adaptation ensured the production of a stable. attenuated $\mathrm{JE}$ line for use as a live virus vaccine.

\section{Arenavirus}

A cold adapted non-virulent variant of the Armstrong strain of lymphocytic choriomeningitis virus (LCMV) was isolated after 17 passages at $25^{\circ} \mathrm{C}$ in $\mathrm{L} 929$ cells $^{15}$. Virus from passage 17 (P17) did not cause death in mice inoculated i.c. with up to 2000 p.f.u. This titre represented $1000 \mathrm{LD}_{50}$ of the parental LCMV. Both the wt LCMV or the ca P17 virus could be isolated in essentially equal amounts from the brains of i.c. inoculated mice. When the brains were compared histopathologically, no histological changes were seen in PI7 virus-infected brains, while the wt LCMV produced evidence of meningitis as early as four days post-infection. No neutralizing antibody and only low levels of complement fixing antibody were detected after infection with P17 virus. These mice were protected to challenge with $100 \mathrm{LD}_{50}$ of parental LCMV, however. PI7 was passaged three times through the mice by i.c. inoculation and the final isolate retained the same biological characteristics of the initial P17 virus. Thus the biological changes in the P17 virus were quite stable.

\section{Paramyxovirus}

Parainfluenza virus type 1 was serially passaged 20 times at $26^{\circ} \mathrm{C}$ in primary African green monkey kidney (AGMK) tissue culture followed by three terminaldilution purifications ${ }^{16}$. After these last three passages the existence of a ts mutant became apparent. This mutant grew poorly at 38 or $39^{\circ} \mathrm{C}$ in tissue culture and also grew poorly in the trachea and lungs of hamsters. The mutant was able to induce almost complete resistance to subsequent replication of wt virus in the lower respiratory tract of inoculated animals for at least two months. While the procedures used in this paper are typical for the production of a cold adapted variant, the results in this case are difficult to interpret because the starting $w t$ parainfluenza type 1 virus grew as well or better at $26^{\circ} \mathrm{C}$ than it did at $35^{\circ} \mathrm{C}$ or $37^{\circ} \mathrm{C}$. In addition, the appearance of the ts mutant occurred after the three terminal-dilution passages, but not before, thus the growth at $26^{\circ} \mathrm{C}$ may not have played a significant role in the selection of this variant

Frickey ${ }^{17}$ attenuated type 3 parainfluenza virus that had been previously passaged in cercopithecus monkey kidney (CMK) tissue culture 45 times at $37^{\circ} \mathrm{C}$, by one passage in CMK cells at $28^{\circ} \mathrm{C}$, followed by 18 passages at $25^{\circ} \mathrm{C}$ (the fourth through the eighth passage at $25^{\circ} \mathrm{C}$ were made using terminal-dilution techniques). The viruses examined were the parental virus, $25^{\circ} \mathrm{C}$ passage- 3 , and $25^{\circ} \mathrm{C}$ passage- 12 . Both $25^{\circ} \mathrm{C}$ passaged viruses grew equally well at 25 or $37^{\circ} \mathrm{C}$, while the parental virus grew 100 -fold less at $25^{\circ} \mathrm{C}$ than at $37^{\circ} \mathrm{C}$. The plaque sizes of both coldadapted viruses were significantly larger than those of the parental virus. Pathogenicity of the parental virus and of the 12 th passage at $25^{\circ} \mathrm{C}$ cold-adapted virus was compared in the lungs of 58-day-old hamsters. Both viruses multiplied rapidly in the lungs on day one. Cold adapted virus titre began to decline after day one, while the parental virus reached its maximum titre on day three. The drop in cold-adapted virus in the lungs of these animals was associated with the early appearance of interferon at days one and two. Equivalent titres of interferon did not appear in the lungs of wt virus-infected hamsters until days four and five. Finally, both wt and cold-adapted viruses produced equal rises in circulating HAI antibodies detectable at days six and seven after inoculation.

Belshe and Hissom ${ }^{18}$ serially passaged the JS strain of parainfluenza type 3 virus three times at $33.5^{\circ} \mathrm{C}$, followed by 10 passages at $22^{\circ} \mathrm{C}$, and finally by 35 passages at $20^{\circ} \mathrm{C}$. Clones were plaque-purified in AGMK cells from passages $7,12,18$, and 45 . At each of these stages the percentage of ts mutations in the population increased: 1 of 9 for passage $-7 ; 3$ of 12 for passage- $12 ; 80 \%$ for passage18: and $100 \%$ for passage-45. Each ts clone also demonstrated a tiny plaque (tp) phenotype. Tp was defined as plaques which were $50 \%$ or less of the wt plaque size. Each ts clone was ca, but not every ca clone was ts. A selected clone from each of the above four passages was further characterized for pathogenicity in weanling hamsters (Hissom and Belshe, personal communication). All four clones were ca, ts and tp. A fifth clone isolated at the 18 th passage which was only ca (non ts and non tp) was also examined. This clone and the clone isolated at the 45 th passage (which was ca, ts, and tp) could not be recovered from the hamsters' turbinates or lungs. The other ca clones grew less in the lungs than in the turbinates not a property of the wt virus. All cold variants were genetically stable in the hamsters except for the virus isolated at the 7 th passage. This partially revertant virus isolated from the nasal turbinate produced small, indistinct plaques at $37^{\circ} \mathrm{C}$, with a 100 -fold decrease in titre at $32^{\circ} \mathrm{C}$. This latter study, unlike the first two, benetited from a plaquing method by which the cold variant viruses could be analysed and titrated.

Studies in our laboratory have adapted recent human isolates of parainfluenza type 1 and 3 viruses to grow in primary chick embyro kidney (PCEK) cells at $35^{\circ} \mathrm{C}$ and these viruses produced $\mathrm{CPE}$ and hence could be plaquepurified. Table 2 presents the tissue culture growth characteristics for a cold adapted type 1 virus after 10 consecutive passages at $25^{\circ} \mathrm{C}$. Similar work is in progress with ca-para-3. 
Table 2 Infectivity titre of a cold-adapted human para-1 (ca-para-1)

\begin{tabular}{llllll}
\hline & $25^{\circ} \mathrm{C}$ & $33^{\circ} \mathrm{C}$ & $35^{\circ} \mathrm{C}$ & $39^{\circ} \mathrm{C}$ & Markers \\
\hline wt-para-1 & no plaque & $2 \times 10^{5}$ & $3 \times 10^{5}$ & $1 \times 10^{4}$ & wt \\
ct-para-1 & $3 \times 10^{3}$ & $5 \times 10^{5}$ & $2 \times 10^{5}$ & $\mathrm{np}$ & $\mathrm{ca}$ ts \\
\hline
\end{tabular}

np, no plaques

\section{Pneumovirus}

Respiratory syncytial virus (RSV) was cold adapted by 21 passages in bovine embryonic kidney culture (BEK) at $34^{\circ} \mathrm{C}$, followed by 12 serial passages at $28^{\circ} \mathrm{C}^{19}$. This virus was terminally diluted three times at $28^{\circ} \mathrm{C}$ and then passaged 16 times at $26^{\circ} \mathrm{C}$. Virus from the $21 \mathrm{st}, 33 \mathrm{rd}$, and 52 nd passage levels was isolated and used for volunteer studies in man. The virus was inoculated intranasally, and was shown to be less infectious and less virulent for man than the wt virus. Virus was plaqued in BEK cells at 28 and $37^{\circ} \mathrm{C}$. Cold-adapted virus gave $37 / 28^{\circ} \mathrm{C}$ titre ratios ranging from 0.04 to 0.4 , while wt virus gave values ranging from 1.4 to 6.2 . Growth of virus at $28^{\circ} \mathrm{C}$ as opposed to $26^{\circ} \mathrm{C}$ did not select for an attenuated virus. Further studies with this ca RSV in infants and in childre ${ }^{20}$ indicated that the virus retained a low level of virulence for individuals undergoing primary infection. Children older than eight months were asymptomatic during infections with this line but did not show local and systemic immune responses. It is possible that a more attenuated and temperature-sensitive virus could be isolated if lower temperatures of 24 or $20^{\circ} \mathrm{C}$ had been used, as was the case for paramyxovirus type $3^{18}$.

A diagramatic illustration of the derivation of cold adapted RSV made in our laboratory is presented in Figure 1. Clone 14 of the cold-adapted RSV was compared to wt RSV in the ferret animal model system. The results are shown in Table 3. The cold-adapted RSV did not grow in the lungs, unlike the wt RSV, and thus was attenuated for ferret. Intranasal administration of clone 14 to chimpanzees showed a moderate degree of reactogenicity (Chanock personal communication). However, the ca
Figure 1 Diagrammatic illustration of the derivation of respiratory synctial (RS) virus cold variant

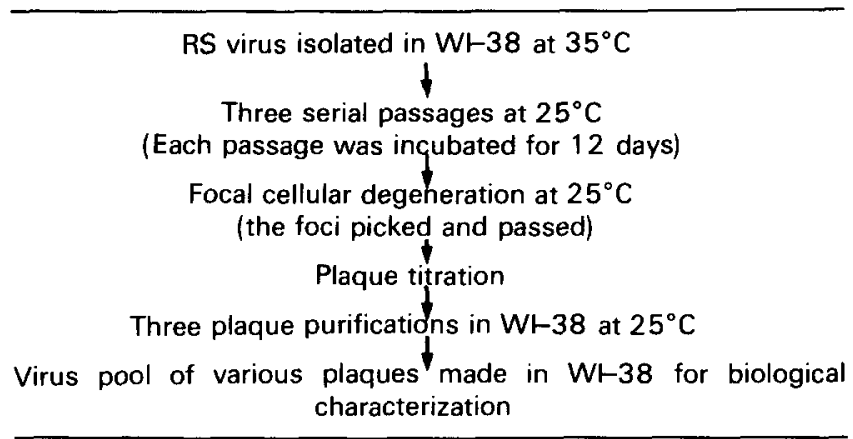

line used was not adequately plaque-purified. The isolated virus also retained its ca and ts markers providing evidence for its phenotypic stability.

\section{Rhabdovirus}

Among other rct/40.5-rabies virus strains, Clark and Wiktor ${ }^{21}$ examined two substrains of challenge-virusstandard (CVS) cultivated at $23-25^{\circ} \mathrm{C}$. Among all the strains examined, there was no consistent correlation between attenuation after intracerebral injection in weanling or newborn mice and temperature sensitivity. By the 50th passage in BHK-21 cells, both cold-adapted virus strains were $\mathrm{rct} / 40.5-$, but neither showed significant attenuation for mice. Attenuated strains of CVS were produced by serial passages in either the viper cell line. VSW, or in the lizard cell line, GLI, and these, likewise, showed no correlation between $\mathrm{rct} / 40.5$ - and attenuation. Selimov and Nikitina ${ }^{22}$ had reported "complete correlation between the degree of temperature sensitivity and attenuation of the SAD strain of fixed rabies virus. The discrepancy between these two reports has not been resolved, although Clark and Witkor ${ }^{21}$ found the lack of correlation between rct/40.5 - and attenuation to be reasonable since

"fever is a late expression of rabies-virus infection", and that

Table 3 Series I, ferret response to the wild type RS virus

\begin{tabular}{|c|c|c|c|c|c|c|c|}
\hline \multirow{3}{*}{ Time postinfection (days) } & \multicolumn{6}{|c|}{ Infectivity titre $\operatorname{TCID}_{50} \mathrm{ml}^{-1}$ at } & \multirow{3}{*}{ Marker } \\
\hline & \multicolumn{2}{|c|}{$25^{\circ} \mathrm{C}$} & \multicolumn{2}{|c|}{$33^{\circ} \mathrm{C}$} & \multicolumn{2}{|c|}{$39^{\circ} \mathrm{C}$} & \\
\hline & $\mathbf{T}$ & $\mathrm{L}$ & $\mathrm{T}$ & $\mathrm{L}$ & $\mathrm{T}$ & $\mathbf{L}$ & \\
\hline $\begin{array}{l}1 \\
3 \\
5 \\
9\end{array}$ & $\begin{array}{l}<1.0 \\
<1.0 \\
<1.0 \\
<1.0\end{array}$ & $\begin{array}{l}<1.0 \\
<1.0 \\
<1.0 \\
<1.0\end{array}$ & $\begin{array}{l}3.0 \\
3.5 \\
4.0 \\
4.3\end{array}$ & $\begin{array}{l}2.0 \\
3.5 \\
4.0 \\
4.0\end{array}$ & $\begin{array}{l}2.3 \\
3.0 \\
4.3 \\
3.5\end{array}$ & $\begin{array}{l}1.5 \\
3.3 \\
3.5 \\
3.0\end{array}$ & $\begin{array}{l}w t \\
w t \\
w t \\
w t\end{array}$ \\
\hline \multicolumn{8}{|c|}{ Series II, ferret response to clone 14, ca - RS virus } \\
\hline \multirow{3}{*}{ Time postinfection (days) } & \multicolumn{6}{|c|}{ Infectivity titre $\mathrm{TCID}_{50} \mathrm{ml}^{-1}$ at } & \multirow{3}{*}{ Marke } \\
\hline & \multicolumn{2}{|c|}{$25^{\circ} \mathrm{C}$} & \multicolumn{2}{|c|}{$33^{\circ} \mathrm{C}$} & \multicolumn{2}{|c|}{$39^{\circ} \mathrm{C}$} & \\
\hline & $\mathrm{T}$ & $\mathrm{L}$ & $\mathbf{T}$ & $L$ & $\mathrm{~T}$ & $\mathrm{~L}$ & \\
\hline $\begin{array}{l}1 \\
3 \\
5 \\
9\end{array}$ & $\begin{array}{l}1.5 \\
2.5 \\
3.0 \\
2.0\end{array}$ & $\begin{array}{r}1.0 \\
1.0 \\
<1.0 \\
<1.0\end{array}$ & $\begin{array}{l}2.5 \\
3.5 \\
4.3 \\
3.0\end{array}$ & $\begin{array}{l}1.5 \\
1.5 \\
1.0 \\
1.0\end{array}$ & $\begin{array}{l}<1.0 \\
<1.0 \\
<1.0 \\
<1.0\end{array}$ & $\begin{array}{l}<1.0 \\
<1.0 \\
<1.0 \\
<1.0\end{array}$ & $\begin{array}{l}\text { ts, ca } \\
\text { ts, ca } \\
\text { ts, ca } \\
\text { ts, ca }\end{array}$ \\
\hline
\end{tabular}

$T$, turbinates; $L$, lungs 
"the fatal outcome of the infection may only be aborted at a very early stage, long before the development of fever".

Experiments with a second Rhabdovirus, vesicular stomatitis virus, by Flamand ${ }^{23}$ supported the findings of Clark and Witkor ${ }^{21}$ in that nine successive passages at $30^{\circ} \mathrm{C}$ in chick embryo fibroblasts caused no apparent genetic effects in the virus. The Rhabdovirus genus appears to be the only virus group examined that does not generally link cold adaptation and attenuation. One reason may be that the starting viruses have already been highly adapted for a particular system, as the fixed CVS rabies line. Rohitayodhin and Hammon ${ }^{13}$ were unable to attenuate a mouse-adapted strain of Japanese B encephalitis virus, but had no problem doing so with a new mosquito isolate.

\section{Herpesvirus}

Herpes simplex virus type I (VR3 strain) and type 2 (MS strain) were cold-adapted at $25^{\circ} \mathrm{C}$ by serial passages in primary chick kidney cells (PCKC) using both liquid overlay and plaquing by Maassab and McFarland ${ }^{24}$. Both cold-adapted type 1 and type 2 viruses grew equally well at either 25 or $35^{\circ} \mathrm{C}$ but were temperature-sensitive at $40^{\circ} \mathrm{C}$. The cold-adapted type 1 virus grew $4 \log$ units less at $40^{\circ} \mathrm{C}$ than it did at $25^{\circ} \mathrm{C}$, and the cold-adapted type 2 virus produced no plaques at all at $40^{\circ} \mathrm{C}$. Both original strains grew equally well at 35 or $40^{\circ} \mathrm{C}$, but not at all at $25^{\circ} \mathrm{C}$. Both cold adapted viruses were shown to be attenuated for mice when inoculated i.c. The cold adapted type 1 virus had a $10^{3.3}$ p.f.u. $/ \mathrm{LD}_{50}$ as compared to 16 p.f.u. $/ \mathrm{LD}_{50}$ for the wt type 1 virus. The cold adapted type 2 virus showed an even more striking loss of virulence. It had a $>10^{6.2}$ p.f.u. $/ L D_{50}$ as compared to 3 p.f.u./ $/ D_{50}$ for the original type 2 virus. Mice which had been inoculated with the cold adapted herpes simplex type 2 virus were shown to be protected against i.c. challenge by $100 \mathrm{MLD}_{50}$ of the virulent parent virus. Histopathological studies by Huang et $a L^{25}$ of mice brain tissue and trigeminal ganglia after i.c. inoculation with either the herpes simplex type 2 parental strain or its cold adapted derivative revealed significant differences in their pathological processes. The wild-type virus caused severe meningitis and necrotic lesions by seven days postinoculation, while the cold adapted virus caused only a mild meningitis and no necrotic lesions. Data suggested that the cold variant virus was unable to lyse its host cell. the neuron, and thus did not spread and continue the infection. The cold mutant of herpes simplex virus type 2 was able to establish a latent state and to persist in the host. The cold variant offers an excellent model system which can be used to study latency and the interaction between host cell and virus, and might give an insight into the mechanisms of naturally occurring HSV infection. Thus, cold selection of a DNA virus yielded a variant population which was temperature sensitive, and due to its restricted ability to grow and spread in vivo was avirulent for mice.

\section{Poxvirus}

Kirn and Braunwald ${ }^{26}$ cold-adapted the mouse virulent WR vaccinia virus strain by stepwise passages from 37 to $25^{\circ} \mathrm{C}$ ( see Table 1 ). The $25^{\circ} \mathrm{C}$ variant gave larger plaques than the parental type and was also more sensitive to temperature effects. The cold variant showed complete loss of virulence when administered i.c. in mice, and was less virulent than the wt in rabbit. Two cold variants of vaccinia virus were made and characterized by Fidzianska ${ }^{27}$. The parental virus was the rabbit skin grown Lister strain, passed twice on chorioallantoic membranes (CAM) of chick embryos and labelled ListerCl. The cold variant Lister- 30 was derived from Lister- $\mathrm{Cl}$ by three passages on CAM at $30^{\circ} \mathrm{C}$. Lister- 22 was derived from Lister- 30 by two passages at $22^{\circ} \mathrm{C}$ in chick embryo cells (CEC), one passage at $37^{\circ} \mathrm{C}$ in CEC, 12 passages at $22^{\circ} \mathrm{C}$ in African Green monkey kidney (AGMK) cells, and finally three passages in CAM at $29^{\circ} \mathrm{C}$. Both viruses resembled the Lister-Cl virus in pock type (opaque, white) although half as large, and all three had the same plaque type (distinct, clear) though the cold variants were $\sim 1.5$ times larger than Lister-C1. Lister- 30 and Lister 22 both had reduced virulence in mice. Lister- 30 was intermediate in virulence between Lister- $\mathrm{Cl}$ and Lister-22. Lister-22 infected mice showed no mortality, while Lister-30 gave $42.8 \%$ mortality, and Lister- $\mathrm{Cl}$ gave $85.7 \%$ mortality. Lister-22 was reduced in infective titre by $3.0 \mathrm{log}$ units at $42^{\circ} \mathrm{C}$. Thus for vaccinia virus, cold adaptation is accompanied by attenuation, moderate temperature sensitivity, and increased plaque size.

\section{Development of cold adapted virus}

\section{Type $A$ influenza virus}

Devising means to control epidemic influenza virus is a challenging problem that has resulted in collaborative research efforts for the development of attenuated live influenza virus vaccine. It is recognized that immunization with live virus may offer many practical and theoretical advantages over immunization with inactivated vaccine. Although various methods have been used in the development of live virus vaccine, the adaptation of the virus to grow at suboptimal temperature $\left(25^{\circ} \mathrm{C}\right)$ has been the most useful approach in terms of genetic stability.

Influenza viruses have been cold-adapted by several groups $^{28-31,78}$. The studies have relied upon pressure selection of a variant which favours growth at $25^{\circ} \mathrm{C}$. or upon chance mutation resulting in a low temperature variant with reduced virulence. The variants derived in some instances did not exhibit optimum growth at $25^{\circ} \mathrm{C}$. In our experience, the simple criteria of in vitro growth at $25^{\circ} \mathrm{C}$ concomitant with a decreased virus yield at supraoptimal temperatures. i.e. $>38^{\circ} \mathrm{C}$. were not acceptable criteria to guarantee delivery of an attenuated virus ${ }^{32}$. It appears that in order to achieve the desired attenuation by cold adaptation, an influenza virus should undergo step-wise or gradual lowering of incubation temperature in primary chick kidney (PCK) cells. This process helps ensure that the selected virus has multiple lesions in its genome resulting in a genetically stable, attenuated coldadapted variant. The presence of multiple lesisons that provide the vaccine with genetic stability fits perfectly with the concept of virulence being polygenic. In addition to a step-wise cold adaptation procedure. the passage level and the host in which it was grown seem to influence the cold adaptation process. For instance, freshly isolated strains at $36^{\circ} \mathrm{C}$ can be adapted to growth at $25^{\circ} \mathrm{C}$ with fewer cultural manipulations than isolates which have been passaged for some time prior to cold adaptation. It is also true that strains isolated in PCK cells require fewer passages at $25^{\circ} \mathrm{C}$ for expression of optimal growth than strains originally isolated in embryonated eggs.

The initial work of adapting influenza virus to grow at $25^{\circ} \mathrm{C}$ was done using a mouse-adapted virulent line of $\mathrm{A}$ AA $/ 6 / 60$ virus and comparing the loss of virulence to the degree of cold adaptation ${ }^{30}$. The results demonstrated that 
Table 4 Passage history of cold variant AVAA6/60 (H3N2), clone 7PI

\begin{tabular}{cl}
\hline Passage level & \\
PCK-1 & Isolation in PCK cell cultures at $36^{\circ} \mathrm{C}$ \\
PCK-2 & Passage in PCK at $36^{\circ} \mathrm{C}$ \\
PCK-3-9 & Serial passage in PCK at $33^{\circ} \mathrm{C}$ \\
PCK-10-16 & Serial passage in PCK at $30^{\circ} \mathrm{C}$ \\
PCK $-17-23$ & Serial passage in PCK at $25^{\circ} \mathrm{C}$ \\
PCK-24-30 & Serial cloning by plaque passages in PCK at \\
& $25^{\circ} \mathrm{C}$ \\
$E-1-3$ & Serial passage in SPAFAS embryonated hens' eggs \\
& at $25^{\circ} \mathrm{C}$
\end{tabular}

Table 5 Markers used to differentiate the cold variant of type A influenza virus from the original strain

\begin{tabular}{|c|c|c|}
\hline Markers & Cold variant & Original strain \\
\hline $\mathrm{pH}$ & Sensitivity to low $\mathrm{pH}$ & $\begin{array}{l}\text { Grow equally well at } \\
\text { low and neutral } \mathrm{pH}\end{array}$ \\
\hline $\mathrm{rct} / 41$ & $\begin{array}{l}\text { Inability to grow at } \\
41^{\circ} \mathrm{C}\end{array}$ & $\begin{array}{l}\text { Grow equally well at } \\
36 \text { and } 41^{\circ} \mathrm{C}\end{array}$ \\
\hline $\begin{array}{l}\text { Plaque size and } \\
\text { shape at } 36^{\circ} \mathrm{C} \\
\text { Plaque size and } \\
\text { shape at } 25^{\circ} \mathrm{C}\end{array}$ & $\begin{array}{l}\text { Small }(<3 \mathrm{~mm}) \\
\text { irregular boundary } \\
\text { Average size } \\
(3-4 \mathrm{~mm}) \text { irregular } \\
\text { boundary }\end{array}$ & $\begin{array}{l}\text { Large }(<4 \mathrm{~mm}) \\
\text { irregular boundary } \\
\text { No plaques }\end{array}$ \\
\hline
\end{tabular}

the emergence of a cold variant was correlated with loss of virulence when the virus was administered intranasally to mice. The cold-adapted line seemed to grow and infect mice without signs of disease and to elicit protective antibody response ${ }^{33}$. Since the passage history of the mouse-adapted line was not acceptable as a vaccine candidate, selection of a cold-adapted mutant with a proven history was accomplished. The Asian strain A/ $\mathrm{AA} / 6 / 60$ ( $\mathrm{H} 2 \mathrm{~N} 2)$ was isolated directly from a throat washing into SPAFAS-derived PCK cells incubated at $37^{\circ} \mathrm{C}$. The process of growing the virus by gradually lowering the temperature of incubation was then undertaken. A gradual lowering of the incubation temperature rather than a sudden sharp decrease was essential for optimal growth. The data seem to indicate that the infectious yield of virus from the initial passage at each particular temperature, starting with $36^{\circ} \mathrm{C}$ and proceeding through $33,30,27$, to $25^{\circ} \mathrm{C}$ was $2-3 \log$ units lower than the 10 th and final passage at the corresponding temperature when the infectious yield was maximal. No change in the titre of the virus was observed upon further passages and no additional benefits were derived upon further lowering of the incubation temperature. The cold variant that was adapted to grow at $25^{\circ} \mathrm{C}$ in PCK cells was then passed at $25^{\circ} \mathrm{C}$ in embryonated eggs with no further adaptation required. The passage history of the cold variant line is illustrated in Table 4 . The virus was found to propagate quite readily in both tissue culture and 10 day old embryonated eggs at $25^{\circ} \mathrm{C}$ with the maximal titre reached between the 3 rd and 4 th day p.i. The cold variant can also be propagated routinely at $33^{\circ} \mathrm{C}$ with a higher yield in a shorter period of time $(48 \mathrm{~h})$. Subsequently, a plaque assay system was developed in PCK cells in order to permit clone purification of cold variants for biochemical and genetic studies ${ }^{34}$. A linear relationship between virus concentration and plaque number was found, and the specificity of the plaques was confirmed using-acute and convalescent serum from a clinical influenza illness. Differences were observed in chick cells infected with the original wild strain and incubated at $25^{\circ} \mathrm{C}$ : there were practically no plaques found at $25^{\circ} \mathrm{C}$ in the culture infected with the original strain even upon a prolonged incubation of two weeks. This difference in plaque formation between the original strain and its cold variant at $25^{\circ} \mathrm{C}$ can be used as a marker differentiating the two lines, and in analysing the progeny virus recovered after administration to experimental animals or man.

The biological characterization of this cold mutant has established markers which can be used to monitor the live virus vaccine in the field, see Table 5. The ca line showed decreased infectious yield at high temperature or at acid $\mathrm{pH}$, and gave distinctive plaque size $\mathrm{e}^{31}$. When evaluated in ferrets and mice the ca Asian strain was found to be genetically stable, attenuated and immunogenic, and to be temperature sensitive with a cut off temperature of $38^{\circ} \mathrm{C}^{33,35,36}$. The A/AA/6/60 ( $\left.\mathrm{H} 2 \mathrm{~N} 2\right)$ ca virus line has been plaque-purified seven times after the step-wise coldadaptation (Table 7) and recent evidence using a combination of different biochemical techniques indicates the existence of mutation(s) in each of the eight genes of the ca line which can account for its genetic stability ${ }^{37}$. Investigations into the genetic basis for the ts phenotype of the ca virus have been reviewed by Kendal et $a b^{38}$. Additional studies are underway to correlate the ca and ts phenotypes to specific gene segments of the virus, with the preliminary evidence favouring a multigenic basis for the ts phenotype in the ca variant ${ }^{37,39}$.

The cold adaptation method was modified for 1965 , 1966 and 1967 strains of type A influenza by using plaquepurified seed virus prior to adaptation. It was possible to adapt an Asian strain of virus to grow at $25^{\circ} \mathrm{C}$ using fewer passages with only one intermediate temperature (Table 6). The selection of a variant with optimal growth at $25^{\circ} \mathrm{C}$ was achieved with only ten passages. It is important at this point to stress that the number of passages required for successful cold adaptation varies between strains - it is not a fixed entity. The number of passages required for obtaining the most vigorous growth at the lower temperature is usually related to the previous passage level of the strain and the kind of host in which it was isolated.

Prior to 1968, attenuation of influenza virus was achieved by gradually lowering the temperature of incubation until optimal growth of virus at $25^{\circ} \mathrm{C}$ was

Table 6 Adaptation of influenza virus $\mathrm{AAA} / 2 / 65-3 \mathrm{PI}^{a}$ to $25^{\circ} \mathrm{C}$

\begin{tabular}{lllr}
\hline $\begin{array}{l}\text { Temperature of } \\
\text { incubation }\left({ }^{\circ} \mathrm{C}\right)\end{array}$ & $\begin{array}{l}\text { No. of passages required } \\
\text { for adaptation }\end{array}$ & 1 st passage & $\begin{array}{c}\text { Infectious titre-p.f.u. } \mathrm{ml}^{-1 b} \\
\text { after adaptation }\end{array}$ \\
\hline 37 & none & $2 \times 10^{7}$ & $2.2 \times 10^{7}$ \\
30 & 4 & $4 \times 10^{4}$ & $4 \times 10^{6}$ \\
25 & 6 & $1 \times 10^{2}$ & $3 \times 10^{6}$ \\
\hline
\end{tabular}

Thrice plaque-purified virus prior to cold adaptation.

op.f.u., plaque forming units 
Table 7 Behaviour of a cold variant A AAV 6/60 (H2N2) after a series of plaque purifications at $25^{\circ} \mathrm{C}$

\begin{tabular}{|c|c|c|c|c|}
\hline \multirow[b]{2}{*}{$\begin{array}{l}\text { No. of Serial } \\
\text { plaque } \\
\text { purifications }\end{array}$} & \multicolumn{3}{|c|}{ Titre in embryonate eggs ${ }^{a}$} & \multirow[b]{2}{*}{$\begin{array}{l}\text { Primary chick kidney } \\
\text { (p.f.u. } \mathrm{ml}^{-1} \text { at } 25^{\circ} \mathrm{C} \text { ) }\end{array}$} \\
\hline & $25^{\circ} \mathrm{C}$ & $35^{\circ} \mathrm{C}$ & $39^{\circ} \mathrm{C}$ & \\
\hline $\begin{array}{l}1 \\
3 \\
7\end{array}$ & $\begin{array}{l}5.3 \\
6.0 \\
7.0\end{array}$ & $\begin{array}{l}7.3 \\
7.0 \\
7.7\end{array}$ & $\begin{array}{l}2.5 \\
1.3 \\
1.0\end{array}$ & $\begin{array}{l}2 \times 10^{5} \\
4 \times 10^{6} \\
5 \times 10^{7}\end{array}$ \\
\hline
\end{tabular}

Figure 2 Flow diagram of cold adaptation of A Aichi/2/68 (H3N2) to $25^{\circ} \mathrm{C}$

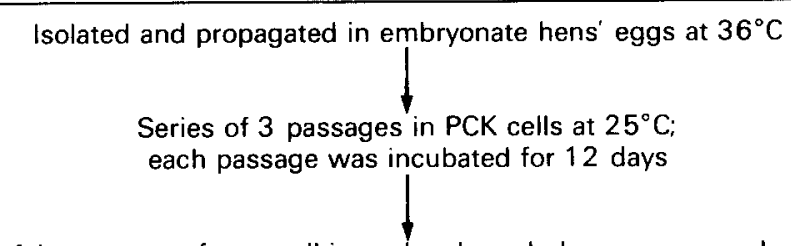

4 th passage - few small irregular shaped plaques appeared on the 10 th day at $25^{\circ} \mathrm{C}$

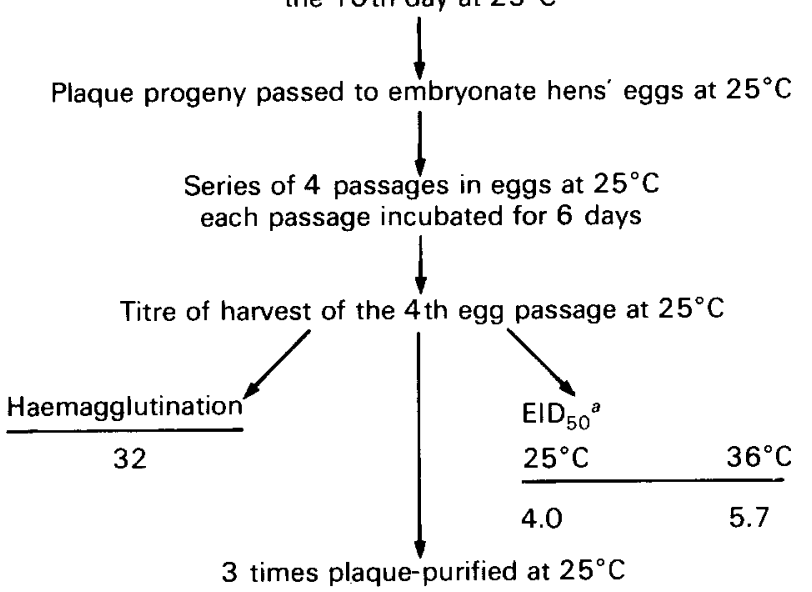

${ }^{a} \mathrm{EID}_{50}$ is expressed as $-\log _{10} \mathrm{EID}_{50} \mathrm{ml}^{-1}$

obtained. The cold variants derived using the 1960, 1965 , and 1967 isolates inducated high antibody levels in infected ferrets and mice without causing illness or pulmonary pathology. However, this process was a lengthy one, requiring six to eight months of effort before a stable nonpathogenic strain was available.

A new procedure based on plaque purification has shortened the process considerably. The temperature of incubation was changed abruptly from $36^{\circ} \mathrm{C}$ to $25^{\circ} \mathrm{C}$ and plaques appearing in tissue cultures held at $25^{\circ} \mathrm{C}$ were the source of virus for further passage in eggs at the low temperature. Figure 2 is a flow diagram which follows the cold adaptation of A/Aichi/2/68 (H3N2) which was achieved in three months. The appropriate tests used for the Asian ca variant were applied to the Hong Kong-like Aichi strain and its wt counterpart. The ca line was ca and ts, and avirulent when tested in ferrets and human volunteers $s^{33,40,41}$. None of the ferrets or human volunteers experienced any unusual symptoms after vaccination. Isolates from these studies were still ts and ca, and no evidence of reversion to wt characteristics was found. With the data presented above( the experience gained over six years of study) and with the proven genetic stability of the cold variants we are able to establish rigid laboratory guidelines which can be followed for development of an acceptable, cold-adapted. live influenza virus vaccine without the necessity of prior testing in man. see Table $8)$.

\section{Type B influenza virus}

The development of cold variants of type B influenza virus was accomplished using the same procedure followed for type A virus. Step-wise lowering of incubation temperature was followed with certain strains in order to obtain cold mutants capable of growing in PCK cells and embryonated eggs at $25^{\circ} \mathrm{C}$. Illustrative findings are shown in Table 9. It was found that to obtain maximum yields at $25^{\circ} \mathrm{C}$, type $\mathrm{B}$ strains required fewer passages at the intermediate temperature than the type $A$ influenza viruses. As in the case of the attenuated type $A$ strains, the cold-adapted type B strains exhibited similar

Table 8 Guideline characteristics of live vaccine strain of influenza virus

(1) Growth at $25^{\circ} \mathrm{C}$ in PCK tissue culture and embryonated eggs. Yield $-\mathrm{HA}=32$ or greater. Infectivity $=10^{6.5} \mathrm{EID}_{50} \mathrm{ml}^{-1}$ or greater

(2) Plaque formation at $25^{\circ} \mathrm{C}$ in PCK tissue culture Infectivity titre $=2 \times 10^{6}$ p.f.u. $\mathrm{ml}^{-1}$ or greater

(3) Plaque morphology at 25 and $33^{\circ} \mathrm{C}$ Size, $3 \mathrm{~mm}$ or greater. Shape, uniform, round

(4) Plaque morphology at $37^{\circ} \mathrm{C}$ Size, $2 \mathrm{~mm}$ or less. Shape, irregular

(5) Temperature sensitivity

No plaques at $40^{\circ} \mathrm{C} .5$ logs or greater decrease in infectious titre in embryonated eggs

(6) Acid lability Plaques are smaller. Decrease in infectious titre of 3-5 logs, in $\mathrm{pH}$ 5.7-6.3

(7) No clinical symptoms in ferrets given intranasal inoculation (Inoculum titre 7.0 logs p.f.u. $\mathrm{m}^{-1}$ )

High $A b$ response $=1: 256$ or greater. Resistant to challenge with $1000 \mathrm{E} \mathrm{D}_{50} \mathrm{ml}^{-1}$ up to 6 months post-inoculation

Table 9 Adaptation of strains of influenza virus type $\mathrm{B}$ to growth at $25^{\circ} \mathrm{C}$

\begin{tabular}{|c|c|c|c|c|c|c|}
\hline \multirow[b]{2}{*}{$\begin{array}{l}\text { Strains of type } \\
B \text { influenza }\end{array}$} & \multirow[b]{2}{*}{$\begin{array}{l}\text { Prior passage } \\
\text { history }\end{array}$} & \multicolumn{4}{|c|}{$\begin{array}{l}\text { No. of passages at various } \\
\text { temperatures required for optimal growth }\end{array}$} & \multirow[b]{2}{*}{$\begin{array}{l}\text { Maximum infectious titre at } \\
25^{\circ} \mathrm{C} \text { in p.f.u. } \mathrm{ml}^{-1}\end{array}$} \\
\hline & & $35^{\circ} \mathrm{C}$ & $33^{\circ} \mathrm{C}$ & $27^{\circ} \mathrm{C}$ & $25^{\circ} \mathrm{C}$ & \\
\hline $\begin{array}{l}\mathrm{B} / \mathrm{CoV} / 1 / 65 \\
\mathrm{~B} / \mathrm{Md} / 59 \\
\mathrm{~B} / \mathrm{Mass} / 3 / 66 \\
\mathrm{~B} / \mathrm{AA} / 1 / 66 \\
\mathrm{~B} / \mathrm{Tec} / 1 / 69\end{array}$ & $\begin{array}{l}\text { MK3-E2 } \\
\text { MK2-E4 } \\
\text { E5 } \\
\text { CK1 } \\
\text { CK1 }\end{array}$ & $\begin{array}{l}3 \\
3 \\
3 \\
2 \\
1\end{array}$ & $\begin{array}{l}4 \\
2 \\
2 \\
2 \\
\end{array}$ & $\begin{array}{l}2 \\
2 \\
2 \\
1 \\
1\end{array}$ & $\begin{array}{l}2 \\
2 \\
1 \\
1 \\
10\end{array}$ & $\begin{array}{l}3 \times 10^{5} \\
4 \times 10^{6} \\
3 \times 10^{6} \\
3 \times 10^{7} \\
5 \times 10^{7}\end{array}$ \\
\hline
\end{tabular}


genetic markers of temperature-sensitivity, sensitivity to acid $\mathrm{pH}$, high yield at $25^{\circ} \mathrm{C}$, and loss of virulence when administered intranasally in ferrets ${ }^{42}$. Two lines of proven and accepted passage history were developed, plaque purified. and characterized in man for use as attenuated live virus vaccines. The cold variants $\mathrm{B} / \mathrm{Ann}$ Arbor/l/366 and $\mathrm{B} / \mathrm{Tecumseh} / 1 / 69$ were plaque-purified in PCK cells at $25^{\circ} \mathrm{C}$ and evaluated in man. These tests gave evidence of genetic stability, immunogenicity and lack of reactogenicity ${ }^{40,41}$.

\section{Production of live influenza vaccine strains by 'cold' reassortment}

As stated previously, considerable effort has been directed toward the development of live attenuated vaccines for the prevention of influenza. These preparations have a number of advantages over the traditional inactivated vaccines, especially with regard to duration and breadth of immunity induced, and the production of local antibody ${ }^{4-46}$. Preparations of such live influenza vaccines pose a particular problem not encountered when dealing with other viruses. The surface antigens of influenza virus change over time, and the vaccine must change accordingly. Thus, not only must the vaccine be safe and effective. but it must also be possible to produce predictably a new effective vaccine variant quickly in response to changes in the circulating viruses.

Certain characteristics of influenza viruses can be transferred between different strains by genetic reassortment (reviewed in Kilbourne ${ }^{47}$ ). It seems likely therefore, that under proper conditions it should be possible to confer, by genetic interchange, the growth characteristics of a previously cold-adapted attenuated strain to a new antigenic variant. Such an accomplishment would considerably shorten the interval between virus isolation and delivery of a suitable seed virus for the production of live vaccine.

Earlier work on the transfer of the ca marker ${ }^{48}$ has shown that a "cold hybrid" of influenza virus can be obtained in five weeks by reassortment at $25^{\circ} \mathrm{C}$. The studies involved the cold variant $\mathrm{A} / \mathrm{PR} 8 / 34$ and a wild type parent A/England/878/69 (H3N2). The cold reassortant contained the haemagglutinin of the current Hong Kong-like parent and the neuraminidase of the established cold mutant. It could grow and produce plaques at $25^{\circ} \mathrm{C}$. It was attenuated for animals (mice) and highly immunogenic. However, the A/PR8/34 cold variant, because of its dubious passage history cannot be used for the production of reassortants as live virus vaccine for man. The availability of a donor line developed in our laboratory and characterized as being suitably attenuated, genetically stable, immunogenic, with defined markers has enabled us to create, in a short period of time, a cold adapted reassortant (these lines are designated $(\mathrm{R})$ bearing the particular contemporary surface antigens desired. Two lines that have been designated as donors of attenuated genes (master strains) are the type $A$ influenza virus $A / A A / 6 / 60(H 2 N 2)$ and the type $\mathrm{B}$ influenza virus $\mathrm{B} / \mathrm{AA} / 1 / 66$. Both cold-adapted lines were cloned at $25^{\circ} \mathrm{C}$ and have been used since 1968 for obtaining cold reassortants for use as attenuated live vaccines $^{49-51}$

In general, PCK cells are simultaneously infected at $25^{\circ} \mathrm{C}$ with approximately 5 p.f.u./cell of the two viruses, i.e. the attenuated donor line and the wild type virus with the relevant surface antigen, as shown in Figure 3 . The duration of the various manipulations from the time of coinfection of PCK cells until the derivation a cold-adapted
Figure 3 Flow Diagram. Tube method for preparation and characterization of cold adapted reassortants from a wild type virus and cold variant $\mathrm{A}$ Ann Arbor $/ 6 / 60$

\begin{tabular}{|c|c|}
\hline Step 1 & $\begin{array}{l}\text { Mixedly infect PCK cells in } 20 \text { tubes with equal input } \\
\text { of } \mathrm{AAA} \vee 6 / 60 \text { cold mutant and wt parent viruses. } \\
\text { Incubate at } 25^{\circ} \mathrm{C} \text { until } \mathrm{CPE} \text { observed. ( } \mathrm{MOI}=5 / \text { p.f.u. } \\
\text { for each parent) }\end{array}$ \\
\hline Step 2 & $\begin{array}{l}\text { Harvest from each tube and repassage separately in } \\
\text { PCK cells at } 25^{\circ} \mathrm{C} \text { in the presence of } \mathrm{NAA} 6 / 60 \\
\text { antiserum }\end{array}$ \\
\hline Step 3 & Repeat Step 2 \\
\hline Step 4 & Repeat Step 2, but omit immune serum \\
\hline Step 5 & $\begin{array}{l}\text { Prepare egg pools for each independent reassortant } \\
\text { line }\end{array}$ \\
\hline Step 6 & Identify $\mathrm{HA}$ and NA antigens for each egg pool \\
\hline Stan 7 & $\begin{array}{l}\text { Grow each separate line or reassortant in PCK cells at } \\
25^{\circ} \mathrm{C} \text { under agar overlay, without immune serum. Pick } \\
\text { one large well-defined plaque for each reassortant } \\
\text { line }\end{array}$ \\
\hline & Repeat Step 7, using virus from plaques of Step 7 \\
\hline $\begin{array}{l}\text { Step } 9 \\
\text { Step } 10\end{array}$ & $\begin{array}{l}\text { Repeat Step 7, using virus from plaques of Step } 8 \\
\text { Verify cold adaptation and temperature sensitivity by }\end{array}$ \\
\hline Step 1 & $\begin{array}{l}\text { Identify the gene constellation of each independent } \\
\text { clone by appropriate electrophoresis techiques }\end{array}$ \\
\hline Step 1 & $\begin{array}{l}\text { On the basis of the above studies, select clones with } \\
\text { the desired properties for evaluation of reactogenicity } \\
\text { in the ferret animal model system }\end{array}$ \\
\hline Step 13 & $\begin{array}{l}\text { Select the clones with the desired in vivo and in vitro } \\
\text { properties for the production and safety-testing of } \\
\text { vaccine pools for human volunteer studies }\end{array}$ \\
\hline
\end{tabular}

reassortment clone(s) with the desired properties is $\sim 5$ weeks. The procedure employed can be relied upon to reproducibly yield suitable candidate vaccine strains if these major conditions are met: (1) vigorous growth with high plaquing efficiency at $25^{\circ} \mathrm{C}$; and (2) temperature sensitivity and loss of virulence in a ferret animal model system.

This procedure involves selective pressure applied to the production of independent appropriately attenuated clones by: (1) the temperature of incubation at $25^{\circ} \mathrm{C}$, at which the wt parent cannot replicate efficiently; and (2) the presence of specific antisera against the surface antigens of the attenuated donor strain. Thus, emergence of cold reassortants bearing the current haemagglutinin and neuraminidase of the virulent wild type parent, but with the growth and other characteristics of the ca master strain is favoured.

The first cold reassortant developed for use as a live virus vaccine in man was designated as AA-CR6-H3N2. It was derived from a mixed infection at $25^{\circ} \mathrm{C}$ in PCK cells of the wt A/Queensland/6/72 (H3N2) with the ca donor line A/AA/6/60 (H2N2). This first reassortant live virus vaccine line was genotyped by Alan Kendal (for review see Kendal et $a .^{38}$ and was shown to have six internal genes of $\mathrm{A} / \mathrm{AA} / 6 / 60$ and the genes coding for the two surface antigens of the wt epidemic strain. The CR vaccine when evaluated in vitro and in vivo had all the desired characteristics of an attenuated vaccine line: it was ca and ts, grew to high titre at 25 and $33^{\circ} \mathrm{C}$, and was attenuated in ferrets with no evidence of reversion to virulence. AA-CR6H3N2 was administered to human volunteers and found to be acceptable as a live virus vaccine strain of influenza virus type ${ }^{\prime} A^{52}$. Since 1975 , reassortment at $25^{\circ} \mathrm{C}$ has been used routinely to derive live virus vaccine candidates for use in $\operatorname{man}^{42,51}$. The colloraborative studies with $\mathrm{Dr}$ Chanock and Dr Murphy at the National Institute of Allergy and Infectious Diseases, and with Dr Kendal and Dr Cox at the Center for Disease Control, have provided 
Table 10 Summary evaluation in vitro and in vivo of vaccine candidates with similar gene composition

\begin{tabular}{|c|c|c|c|c|}
\hline \multirow[b]{2}{*}{ Vaccine line $e^{b}$} & \multirow[b]{2}{*}{ Wild type parent } & \multirow[b]{2}{*}{ Clinical signs $^{c}$ (ferrets) } & \multicolumn{2}{|c|}{ Histopathology $y^{d}$} \\
\hline & & & $T$ & $\mathbf{L}$ \\
\hline $\mathrm{AA}-\mathrm{CR} 6-\mathrm{H} 3 \mathrm{~N} 2$ & A/Queensland $/ 6 / 72$ & absent & $1+$ & 0 \\
\hline AA-CR29 C1-17 & A Alaska $6 / 77$ & coryza 1 day & $2+$ & 0 \\
\hline AA-CR31-H3N2 C1-2 & A Alaska $6 / 77$ & coryza 1 day & $1+$ & 0 \\
\hline AA-CR31-H3N2 C1-13 & A Alaska $6 / 77$ & absent & 0 & 0 \\
\hline AA-CR33-H1 N1 C1-1 & A USSR/90/77 & absent & 0 & 0 \\
\hline AA-CR35-H1 N1 C1-2 & A $/ H K / 123 / 77$ & absent & 0 & 0 \\
\hline AA-CR37-H1N1 C1-1 & $\mathrm{A} / \mathrm{Cal} 10 / 78$ & absent & $1+$ & 0 \\
\hline AA-CR44-H3N2 C1-6 & A Beijing $/ 2 / 79$ & coryza 2 day & $1+$ & 0 \\
\hline $\mathrm{AA}-\mathrm{CR} 48-\mathrm{H} 3 \mathrm{~N} 2 \mathrm{Cl}-4$ & A W Wash $/ 897 / 80$ & coryza 1 day & $2+$ & 0 \\
\hline AA-CR5 1-H1 N1 C1-1 & A Shanghai $31 / 80$ & absent & 0 & 0 \\
\hline AA-CR59-H3N2 C1-19 & A Korea $1 / 82$ & coryza 1 day & $1+$ & 0 \\
\hline
\end{tabular}

${ }^{a}$ No reversion to tst, cat in PCK tissue culture was seen for any of these cold reassortants reisolated from ferrets. ${ }^{b}$ The infectious dose administered to ferrets intranasaliy ranged from 7.7 to $8.3 \log _{10} E_{1 D_{50}} \mathrm{ml}^{-1}$. ${ }^{c}$ No fever was shown. ${ }^{d} \mathrm{~T}$, turbinates; $\mathrm{L}$, lungs; $1+$, minor changes; $4+$, major changes

Table 11 AA-CR48 genotype A Washington $897 / 80 / W T \times A \vee A A / 6 / 60$, 'donor line'

\begin{tabular}{|c|c|c|c|c|c|c|c|c|}
\hline Virus $\mathrm{RNA}^{a}$ protein & $\begin{array}{l}1 \\
\text { P2 }\end{array}$ & $\begin{array}{l}2 \\
\text { P3 }\end{array}$ & $\begin{array}{l}3 \\
\mathrm{P} 1\end{array}$ & $\begin{array}{l}4 \\
\mathrm{HA}\end{array}$ & $\begin{array}{l}5 \\
\text { NA }\end{array}$ & $\begin{array}{l}6 \\
\text { NP }\end{array}$ & $\begin{array}{l}7 \\
M\end{array}$ & $\begin{array}{l}8 \\
\text { NS }\end{array}$ \\
\hline $\begin{array}{l}\text { A AA/6/60 } \\
\text { A } / \text { Wash } / 847 / 80 \\
\text { CR48 }\end{array}$ & $\begin{array}{l}A^{c} \\
W^{d}\end{array}$ & $\stackrel{A}{W}$ & $\begin{array}{l}A \\
W\end{array}$ & $\begin{array}{l}A \\
W\end{array}$ & $\begin{array}{l}A \\
W\end{array}$ & $\stackrel{A}{W}$ & $\begin{array}{l}A \\
W\end{array}$ & $\begin{array}{l}A \\
W\end{array}$ \\
\hline $\begin{array}{l}\text { cl } 1-1-3 \mathrm{PI} \\
\text { cl } 2-1-3 \mathrm{PI} \\
\text { cl } 3-1-3 \mathrm{PI} \\
\text { cl } 4-1-3 \mathrm{PI}\end{array}$ & $\begin{array}{l}\text { W } \\
\text { W } \\
A \\
A\end{array}$ & $\begin{array}{l}A \\
A \\
A \\
A\end{array}$ & $\begin{array}{l}\text { W } \\
\text { W } \\
A \\
A\end{array}$ & $\begin{array}{l}W \\
W \\
W \\
W\end{array}$ & $\begin{array}{l}W \\
W \\
W \\
W\end{array}$ & $\begin{array}{l}W \\
W \\
A \\
A\end{array}$ & $\begin{array}{l}A \\
A \\
A \\
A\end{array}$ & $\begin{array}{l}\text { W } \\
W \\
\text { W } \\
\text { A (vaccine } \\
\text { line) }\end{array}$ \\
\hline
\end{tabular}

a Numbers refer to migration of RNA segments on a mized $0.6 \%$ agarose- $3.0 \%$ polyacrylamide gel made with TBE buffer, pH 8.3 run at $37^{\circ} \mathrm{C}$ and $30^{\circ} \mathrm{C}$ for 30 and $18 \mathrm{~h}$, respectively. ${ }^{\circ} \mathrm{P} 1, \mathrm{P} 2$, and $\mathrm{P} 3$ refer to the order of migration of the polymerase proteins on high resolution Laemmli gels (7\% acrylamide separation gel). ${ }^{\circ} \mathrm{A}$ represents genes derived from $\mathrm{A} A \mathrm{AA} 6 / 60 .{ }^{d} \mathrm{~W}$ represents genes derived from the wild-type parent, AvWashington $897 / 80$

the basis for the establishment of the biological and biochemical criteria for the use of cold reassortants as candidates for live influenza virus vaccines. The data presented in Table 10 provide a summary of the cold reassortants derived in this laboratory with the $6 / 2$ gene configuration that have been documented as being ca and ts, and are genetically stable showing no evidence of reversion to wt characteristics and no manifestations of wt clinical symptoms when administered intranasally to ferrets $^{51}$

The production and characterization of AA-CR48H3N2 followed the procedures outlined in the flow diagram shown in Figure 3, and will be used as a typical example of the production of a vaccine candidate. The wild type virus, A/Wash/897/80 (H3N2) was cloned at $39^{\circ} \mathrm{C}$ in primary bovine kidney cells by Dr Brian Murphy (NIAID), and found to be virulent when given to human volunteers. The gene constellations of selected clones are shown in Table 11. Clone 4 was chosen as the vaccine candidate on the basis of its $6 / 2$ gene constellation. The AA-CR48 (H3N2) vaccine line was evaluated for virulence in animals. Ferrets were used at four months old and were screened for the presence of pre-existing antibody to the influenza virus being administered. They were found to be seronegative prior to use. They were inoculated intranasally using a high dose of CR48 clone 4 , with parallel sets of animals used for infection with parent strains. Results shown in Table 12 represent the data for two lots of the AA-CR48 (H3N2) clone 4 produced and safety-tested by Dr Louis Potash (Flow Laboratories,
McLean, VA) when administered to immunologically naive ferrets and compared to the two parental strains. It is evident that the cold reassortant line was attenuated and acceptable for use as live virus vaccine in man. Recent studies in seronegative human volunteer ${ }^{53,54}$ confirmed and extended prior studies that demonstrated that the CR vaccine lines with $6 / 2$ gene constellation, were not reactogenic in adults, were genetically stable, antigenic, and were found to induce better resistance than inactivated vaccine to experimental challenge. The cold reassortants with the $6 / 2$ gene constellation were also tested in young seronegative children and were found to induce humoral and cellular immune responses, to be attenuated, to be genetically stable and to confer significant protection as evaluated by serologic evidence of protection $^{55,56}$

As stated above, the transfer of the ca property was always performed at $25^{\circ} \mathrm{C}$. It has also been shown that the "cold' genes of the master strain can be transferred at the permissive $\left(33^{\circ} \mathrm{C}\right)$ and the non-permissive $\left(38^{\circ} \mathrm{C}\right)$ temperatures, with the retention of both ca and ts markers ${ }^{57,58}$. The clones isolated at either temperature were also found to be attenuated in ferrets. Thus, the ca property of the cold mutant is a stable property which can be transferred regardless of the temperature used during reassortment.

Recently we isolated some limited gene reassortants of A/AA/6/60 (H2 N2) X A/Alaska/6/77 (H3N2) viruses and demonstrated that the ca property can be segregated from the ts property at either 25 or $33^{\circ} \mathrm{C}^{39}$. Analysis of these clones was performed to explore the functions of both the 

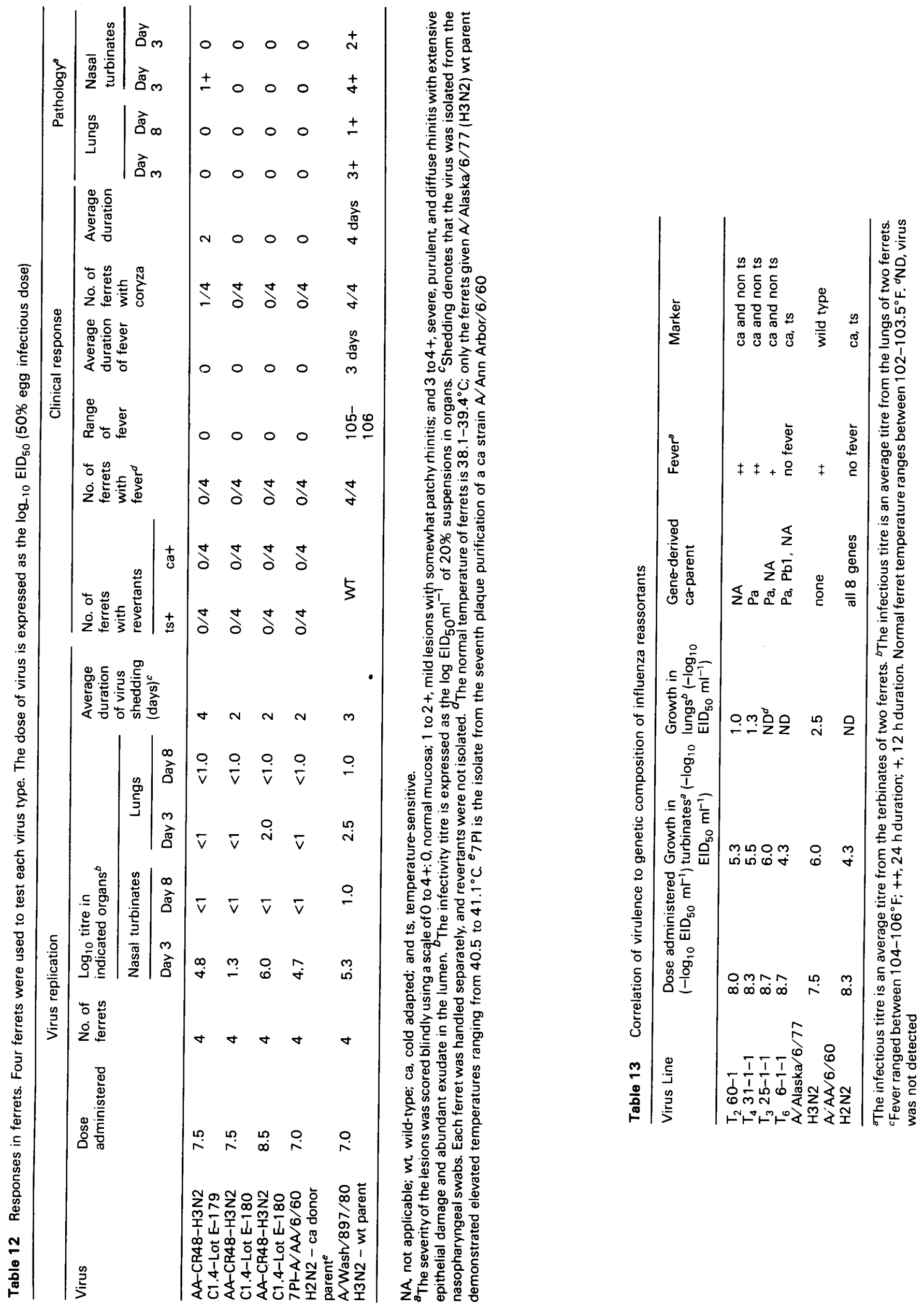
Table 14 Behaviour of cold reassortants with varying gene composition

\begin{tabular}{|c|c|c|c|c|}
\hline Cold Reassortant (wt-parent) & WT-derived gene & Ferret response & Reversion & Behaviour in man \\
\hline $\begin{array}{l}\text { AA-CR } 18-H 3 N 2 \\
(A \vee S \cot / 840 / 74)\end{array}$ & HA NA NS & $\begin{array}{l}\text { Reactogenicity at }>8.3 \text { logs } \\
\text { infectious dose }\end{array}$ & Yes & Same as in ferrets \\
\hline $\begin{array}{l}\text { AA-CR22-H3 Nw } \\
\text { (A Victoria } 3 / 75 \text { ) } \\
\text { AA-CR22-H3 N2 } \\
\text { (A Victoria/3/75) }\end{array}$ & $\begin{array}{l}\text { HA, NA, } \mathrm{Pb} 1 \\
\text { HA, NA, Pb1 }\end{array}$ & $\begin{array}{l}\text { Mild reaction at }>8.3 \text { logs } \\
\text { infectious dose } \\
\text { (same as above) }\end{array}$ & $\begin{array}{l}\text { No } \\
\text { No }\end{array}$ & $\begin{array}{l}\text { Attenuated } \\
\text { Attenuated }\end{array}$ \\
\hline $\begin{array}{l}\text { AA-CR31-H3N2 } \\
\text { Clone } 3\end{array}$ & HA, NA, M & Attenuated & tst, ca & Attenuated \\
\hline $\begin{array}{l}\text { Clone } 10 \\
\text { (A Alaska/6/77) }\end{array}$ & HA NA NS & Attenuated & No & Attenuated \\
\hline $\begin{array}{l}\text { AA-CR48-H3N2 } \\
\text { Clone } 2 \\
(A \sim \text { Wash } / 897 / 80)\end{array}$ & $\begin{array}{l}\mathrm{HA}, \mathrm{NA}, \mathrm{Pb} 1 \\
\mathrm{~Pb} 2 \mathrm{NP}, \mathrm{NS}\end{array}$ & Mild fever & $\mathrm{ts}+\mathrm{ca}$ & Attenuated \\
\hline
\end{tabular}

ca and ts properties with respect to virulence in animals. Data suggested that limited viral replication in mouse lungs was related to the increasing number of ca genes transferred from the master strain to the reassortants. The findings also imply that the ca characteristics of $\mathrm{A} / \mathrm{AA} / 6$ / 60 donor virus play a supporting role to its ts characteristics in alteration of virulence in the cold reassortants ${ }^{59}$. In addition, studies in ferrets using these same reassortants with the "limited" gene composition showed the same correlation between a decrease of virulence with the increasing number of $\mathrm{A} / \mathrm{AA} / 6 / 60$ genes present in the cold reassortant. The data in Table 13 provide evidence that the two cold reassortants containing single A/AA/6/60 genes, either the polymerase $(\mathrm{Pa})$ or the neuraminidase (NA) gene. showed little attenuation in ferrets from the wt parent. However, the cold reassortant containing both of these genes showed some decrease in virulence compared to the wt parent. Finally, a reassortant containing three $\mathrm{A} / \mathrm{AA} / 6 / 60$ genes, polymerases ( $\mathrm{Pb} 1 . \mathrm{Pa}$ ) and NA. was ca and ts, and had an attenuation in ferrets equal to that of the cold-adapted parent $\mathrm{A} / \mathrm{AA} / 6 / 60$.

Examination of clones of differing gene composition established that correlation does exist between the gene( $s$ ) derived from the wt virus, and the reactogenicity of the cold reassortants as shown in Table 14 $4^{50,51}$. Although all the clones tested were definitely attenuated when compared to the wt virus, reversion to $\mathrm{ts}^{+}$and some reactogenicity were noted at doses $>10^{8.3} \mathrm{EID}_{50} \mathrm{ml}^{-1}$. In addition, infection of ferrets with lines showing reversion to $\mathrm{ts}^{+}$but retention of the ca marker did not show any loss of their previous attenuation. Results of trials in human volunteers using AA-CR31, clones 3 and $10^{36}$ showed that the two lines were infectious and attenuated, and demonstrated that the matrix (M) and non-structural (NS) genes were not the major determinants of attenuation ${ }^{61,62}$. Correlation of gene composition to attenuation has also been explored by Ghendon et $a l^{63}$ using cold-adapted and virulent strains developed in the USSR. Their conclusion also fits the concept that the more genes transferred from the ca donor virus to the reassortant, the more stable its attenuated phenotype will be.

Efforts to link the ca and ts phenotypes of $\mathrm{A} / \mathrm{AA} / 6 / 60$ cold variant virus to specific genes has met with only limited success for a number of reasons. Until recently there have been a limited number of reassortants with different gene constellation and none with only single genes from $\mathrm{A} / \mathrm{AA} / 6 / 60$. In addition, studies have indicated that both ca and ts phenotypes are complex in nature, involving more than a single gene $\mathrm{each}^{37,39}$. The genes needed to confer the ts phenotype varied depending upon the wt parent used ${ }^{37,64}$. Work is proceeding in this laboratory to generate a library of reassortants with a wide range of different gene constellations in an attempt to generate better evidence for the correlation of ca. ts, and attenuated phenotype to specific genotypes in the cold reassortants.

For the present and from a practical consideration. it can be stated that cold reassortants with the two wt genes coding for the two surface glycoprotein genes and the remaining six genes from the cold-adapted parent will be best suited as live virus vaccines to be used in man.

Studies in the development of cold reassortants of influenza type $B$ viruses are being pursued along the same lines used to develop cold reassortants of type A influenza viruses. Earlier in this chapter we have stated that a type $B$ ca strain, $\mathrm{B} / \mathrm{AA} / \mathrm{1} / 66$ of proven attenuation in ferrets and $\operatorname{man}^{40}$ has been designated as the ca donor line 'master strain' for the production of type B influenza reassortants. Table 15 summarizes the type B influenza cold adapted mutants and the cold reassortant derived by reassortment at $25^{\circ} \mathrm{C}$ in PCK cells. The cold reassortants when tested in human volunteers ${ }^{52,65}$ in various geographic areas were found to be attenuated, had ca and ts markers, and gave no evidence of transmission to contacts. The immuno-

Table 15 The candidate vaccine lines of type B influenza virus administered to human volunteers

\begin{tabular}{|c|c|c|c|}
\hline Virus line & Derivation & Testing in man & $\begin{array}{l}\text { Immuno- } \\
\text { genicity }{ }^{a}\end{array}$ \\
\hline $\begin{array}{l}\text { B/AA } 1 / 66 \\
\text { Master Strain }\end{array}$ & CV, Stepwise & $\begin{array}{l}\text { Common Cold } \\
\text { Unit-England }\end{array}$ & High \\
\hline $\mathrm{B} / \mathrm{Tec} / 1 / 69$ & CV, Stepwise & NAMRU-4 & Moderate \\
\hline $\begin{array}{l}\text { AA-CR7 } \\
(B / H K / 8 / \\
73 \times B / A A / 66)\end{array}$ & Reassortant & $\begin{array}{l}\text { Different } \\
\text { areas }\end{array}$ & $\begin{array}{l}\text { Moderate to } \\
\text { high }\end{array}$ \\
\hline $\begin{array}{l}\mathrm{AA}-\mathrm{CR} 17 \\
(\mathrm{~B} / \mathrm{AA} / 1 / \\
74 \times \mathrm{B} / \mathrm{AA} / 66)\end{array}$ & Reassortant & Overseas & Low \\
\hline $\begin{array}{l}\text { RB-77-SFI } \\
\text { (B/Tec/10/ } \\
77 \times B / A A / 66)\end{array}$ & Reassortant & $\begin{array}{l}\text { Different } \\
\text { areas }\end{array}$ & Moderate \\
\hline
\end{tabular}

${ }^{2}$ As evaluated by seroconversion rate and clinical manifestations High $=<75 \%$ seroconversion. Moderate $=50-75 \%$. Low $=<50 \%$ $<50 \%$ 
genicity of these cold reassortants ranged from low (50\%) seroconversion after immunization with AA-CR17 type B reassortant through moderate $(\sim 60 \%)$ seroconversion, to high $(\sim 75 \%)$ seroconversion after the administration of AA-CR7 type B reassortant. The work with influenza type $B$ cold reassortants is embryonic. Electrophoretic methods of genotyping the parental origin of all eight RNA segments is available and similar to that used for type A viruses. Definite protein-gene assignments are in progress, and will be completed soon. Emphasis in the near future will be to develop and characterize new type $B$ cold reassortants for use with type $\mathrm{A}$ cold reassortants as bivalent live influenza virus vaccine.

\section{Conclusions}

Viruses of almost every RNA virus genus and of two DNA virus genera have been cold adapted to grow at temperatures suboptimal for their normal growth. In almost all cases there has been correlation of the acquisition in these viruses of temperature sensitivity in tissue culture, and attenuation in the normal host: animal or man. In only a few instances did this correlation break down, see Rhabdovirus genus, above. Even in this genus there are conflicting reports, and the resolution may lie in the manner in which the cold adaptation was performed and the strain of virus used. The most successful method of cold adaptation for developing a live virus vaccine line appears to be a stepwise lowering of the incubation temperature, allowing time for multiple cold-adapted lesions to occur and/or be selected for in the viral genome. Plaque-purification and screening of virus for desired traits at different stages of the stepwise adaptation is the most efficient way to achieve the desired strain. If the starting virus is a recent isolate which has not already been extensively adapted to a particular host cell system the cold adaptation process appears to proceed more easily and with better and more consistent results. In most cases the adaptation process is performed in tissue culture in a heterologous host from the viruses normal host in nature. Thus, while the virus is being cold-adapted it may also be host-adapted. This adaptation may complicate the linkage of attenuation to specific cold adapted genes, but practically it may be an asset in the production of a stable, attenuated virus variant. Finally, for many virus diseases, cold adaptation can provide suitable live virus vaccine candidates capable of providing safe, efficient protection from wild type virus challenge.

\section{Acknowledgements}

The authors wish to thank the support and collaborative efforts of Drs R Chanock and B. Murphy of the Laboratory of Infectious Diseases, Bethesda, MD, USA. Dr John La Montagne. Development and Application Branch, NIAID, USA and Drs A. Kendal and N. Cox of the Center for Disease Control, Atlanta, GA, USA.

We thank C.W. Smitka, L. Allen, S. Powell and K Wandersee for their expert technical assistance.

The early research from this laboratory on influenza viruses was supported in part by the US Army Medical Research and Development Command. Department of the Army, Contract Nos. DA-49-193-MD-2066, DADA-17-70-C-0050 and DADA-17-C-3060.

The work on parainfluenza viruses and respiratory syncytial virus was supported by Contract No. 80-1368$\mathrm{Cl}$ of Sandoz Forschung Institute, Vienna. Austria.
Since 1976, the research on influenza virus was supported by Contract No. 1-AI-72521 and No. 1-AI52564, National Institute of Allergy and Infectious Diseases, Development and Application Branch, Bethesda, Maryland 20205, USA

\section{References}

1 Sabin, A Reproductive capacity of poliovirus of diverse origins at various temperatures. Perspect Virol. 1961, 2, 90

2 Enders, J.F. and Shaffer, M.F. Studies on natural immunity to pneumococcus type III. Capacity of strains of pneumococcus type III to grow at $41^{\circ} \mathrm{C}$ and their virulence for rabbits. J. Exp. Med. 1936, 64, 7

3 Burnet, F.M. The use of the developing egg in virus research. London, H.M. Stationary Office, (Great Britain Medical Research Council, Special Report Series No. 220), 1936

4 . Fenner, F. Conditional lethal mutants of animal viruses. Curr. Top. Microbiol. 1969, 48, 1

5 Ghendon, Y.Z. Conditional-lethal mutants of animal virus. Prog. Med. Virol. 1972, 14,68

6 Dubes, G.R. and Chapin, M. Cold-adapted genetic variants of polio viruses. Science 1956, 124, 586

7 Dubes, G.R. and Wenner, H.R. Virulence of polioviruses in relation to variant characteristics distinguishable on cells in vitro. Virology 1957, 4, 275

8 Lwoff, A Factors influencing the evolution of viral diseases at the cellular level and in the organism. Bacteriol. Rev. 1959, 23 109

9 Koprowski, H., Carp, R., Norton, T.W., Cohen, B. and Plotkin, S.A The application of genetic markers to the development and control of live poliovirus vaccine. In: Live poliovirus vaccines. (Second International Conference on Live Poliovirus Vaccines) WHO, Wash. DC 1960, pp. 53-65

10 Sabin, A Behavior of cold mutants of poliovirus in human beings. In: Live poliovirus vaccines. (Second International Conference on Live Poliovirus Vaccines). WHO, Wash. DC, 1960. pp. $101-108$

11 Jablonski, L. Studies on echo 9 virus II. Biological properties of the "cold" mutant. Exp. Med. Microbiol. 1968, 20, 55

12 Gevaudan, P., Charrell, J., and Pieroni, G. Recherches sur un variant 'froid' de virus coxsackie. Ann. Inst Pasteur (Paris) 1968, 114, 209

13 Rohitayodhin, S. and Hammon, W. McD. Studies on Japanese $B$ encephalitis virus vaccines from tissue culture. II. Development of an attenuated strain of virus. J. Immunol. 1962, 89. 589

14 Yoshida, I., Takagi, M., Inokuma, E., Goda H., Ono, K., Takaku, K et al. Establishment of an attenuated ML-17 strain of Japanese encephalitis virus. Biken J. 1981, 24, 47

15 Brayton, P.R. and Maassab, H.F. Characterization of lymphocytic choriomeningitis virus. Arch. Virol. 1982, 74, 85

16 Potash, L., Lees, R.S., Greenberger, J.L., Hoyrup, A., Denney, L.D. and Chanock, R.D. A mutant of parainfluenza type 1 virus with decreased capacity for growth at $38^{\circ} \mathrm{C}$ and $39^{\circ} \mathrm{C} . \mathrm{J}$. Infect. Dis. 1970, 121, 640

17 Frickey, P.H. Markers differentiating type 3 parainfluenza virus grown at 25 and $37^{\circ} \mathrm{C}$. Applied Microbiol. 1969, 17, 589

18 Belshe, R.B. and Hissom, F.K. Cold adaptation of parainfluenza virus type 3: Induction of three phenotypic markers. J. Med. Virol. 1982, 10, 235

19 Friedewald, W.T., Forsyth, B.R., Smith, C.D., Gharpure, M.A and Chanock, R.M. Low-temperature-grown RS virus in adult volunteers. J. Am. Med Assoc. 1968, 204, 690

20 Kim, H.W., Arrobio, J.O., Pyles, G., Brandt C.D., Camargo, E.. Chanock, R.M. and Parrott, R.H. Clinical and immunological response of infants and children to administration of low temperature adapted respiratory syncytial virus. Pediatrics $1971,48,745$

21 Clark, H.F. and Witkor, T.J. Temperature-sensitivity characteristics distinguishing substrains of fixed rabies virus: Lack of correlation with plaque-size markers or virulence for mice. $J$. Infect. Dis. 1972, 125, 637

22 Selimov, M.A. and Nikitina, L. F. The rct 40 marked fied rabies virus. Vopr. Virusol. 197015,161

23 Flamand, A Genetical behavior of vesicular stomatitis virus during successive passages at high and low temperatures. Mutat. Res. 1973, 17, 177 
24 Maassab, H.F. and McFarland, C.R. Characterization of herpes simplex virus types 1 and 2 adapted to growth at $25^{\circ} \mathrm{C} . \mathrm{J}$. Gen. Virol. 1973, 19, 151

25 Huang, D.D., Abrams, G.D. and Maassab, H.F. Neurological involvement in mice after infection with a cold-adapted herpes simplex type 2 virus. Infect Immun. 1982, 35, 1070

26 Kirn, A and Braunwald, J. Selection par passages a basse temperature d'un variant 'froid' a virulence attenuee du virus vaccinal. Ann. Inst. Pasteur (Paris) 1964, 106, 427

27 Fidzianska, E. Temperature mutants and recombinants of vaccinnia virus: I. Genetic characteristics of temperature mutants. Acta. Virol. 1972, 16, 291

28 Alexandrova, G.I. and Smorodinstev, A.A. Obtaining of an additionally attenuated vaccinating cryophil influenza strain. Rev. Roum. Inframicrobiol. 1965, 2, 197

29 Smorodinstev, A. The efficacy of live influenza vaccine. Bull. WHO 1969, 41, 585

30 Maassab, H.F. Adaptation and growth characteristics of influenza virus at $25^{\circ} \mathrm{C}$. Nature $1967,213,612$

31 Maassab, H.F. Biologic and immunologic characteristics of cold-adapted influenza virus. J. Immunol. 1969, 102, 728

32 Van Kirk, J.E. Mills, J.V. and Chanock, R.M. Evaluation of low temperature grown influenza $\mathrm{A} 2$ / Hong Kong virus in volunteers. Proc. Soc. Exp. Biol. Med. 1971, 136, 34

33 Maassab, H.F., Francis, Jr. T., Davenport, J.F., Hennessy, A.V., Minuse, E. and Anderson, G. Laboratory and clinical characteristics of attenuated strains of influenza virus. Bull. WHO $1969,41,589$

34 Maassab, H.F. Plaque formation of influenza virus at $25^{\circ} \mathrm{C}$. Nature 1968, 219,645

35 Kitayama, T., Togo, Y., Hornick, R. B. and Friedewald, W.T. Lowtemperature-adapted influenza A2/AA $6 / 60$ virus vaccine in man. Infect. Immun. 1973, 7, 119

36 Murphy, B.R., Chanock, R.M., Clements, M.L., Anthony, W.C., Sear, A.J., Cisneros, LA et al. Evaluation of A/Alaska/6/77 (H3N2) cold adapted recombinant viruses derived from $A$ Ann Arbor $/ 6 / 60$ cold-adapted donor virus in adult seronegative volunteers. Infect Immun. 1981, 32, 693

37 Cox, N.J., Kendal, A.P., Maassab, H.F., Scholtissek, C. and Spring, S.B. Genetic synergism between matrix protein and polymerase protein required for temperature sensitivity of the cold-adapted influenza $A$ Ann Arbor/6/60 mutant virus. In: The Replication of Negative Strand Viruses. (Eds Bishop D.S.L. and Compans, R.W.) New York, Elsevier/North Holland, 1981, Vol. 7, pp. 405-413

38 Kendal, A.P., Maassab, H.F., Alexandrova, I. and Ghendon, $Y$. Development of cold adapted recombinant live-attenuated influenza $A$ vaccines in the U.S. and U.S.S.R. Antiviral Res. $1981,1,339$

39 Odagiri, T. DeBorde, D.C. and Maassab, H.F.J. Cold-adapted recombinants of influenza A virus in MDCK cells. Virology, $1982,119,82$

40 Beare, A.S., Maassab, H.F., Tyrrell, D.A.J., Slepuskin, A.N. and Hall, T.S. A comparative study of attenuated influenza viruses. Bull. WHO 1971, 44, 593

41 Davenport, F.M., Hennessy, A.V., Minuse, E., Maassab, H.F. Anderson, G.R., Mitchell, J.R. et al. Pilot studies on mono and bivalent live attenuated influenza virus vaccines. Proc. Symp Live Influenza Vaccine. Yugoslav Academy of Sciences and Arts, Zagreb 1971, pp. 105-113

42 Maassab, H.F., DeBorde, D.C., Cox, N.J. and Kendal, A.P. Development of cold-recombinants of influenza virus as live virus vaccines. In: Genetic variation among influenza viruses. (Ed. Nayak, D.) New York, Academic Press, 1981, Vol. 16, pp. 617-637

43 Clements, M.L. O'Donnell, S. Levine M.M. Chanock, R.M and Murphy, B.R. Dose response of A Alaska/6/77 (H3N2) cold adapted reassortant vaccine virus volunteers: Role of local antibody in resistance to infection with vaccine virus. Infect. Immun. 1983, 40, 1044

44 Murphy, B. R., Nelson, D.L., Wright, P.F., Tierney, E. L., Phelan, M.A and Chanock, R.M. Secretory and systemic immunological response in children infected with live attenuated influenza A virus vaccine. Infect. Immun. 1982, 36, 1102

45 Nai-ki, M. Yong-He, Z., Ada, G.L. and Tannock, G.A. Humora and cellular responses of mice to infection with a cold-adapted influenza A virus variant. Infect. Immun. 1982, 38, 218

46 Yarchoan, R., Murphy, B. R., Strober, W. Clements, M.L and Nelson, D. L. In vitro production of anti-influenza virus antibody after intranasal inoculation with cold-adapted influenza virus. J. Immunol. 1981, 127, 1958
47 Kilbourne, E. (Ed.) The influenza viruses and influenza, Academic Press, New York. 1975, pp. 1-573

48 Maassab, H.F., Kendal, A.P. and Davenport, F.M. Hybrid formation of influenza virus at $25^{\circ} \mathrm{C}$. Proc. Soc. Exp. Biol. Med. 1972, 139, 768

49 Maassab. H.F. Properties of influenza virus 'cold-recombinants' In. Negative Strand Viruses. (Eds Barry, R.D. and Mahy, B.W.J.) New York, Academic Press, 1976, pp. 755-763

50 Maassab, H.F. Spring S.B., Kendal, A.P. and Monto, A.S Biologic characteristics of influenza virus recombinants derived at sub-optimal temperatures: In: Negative strand viruses and the host cell. (Eds Mahy, B.W.J. and Barry, R.D.) New York, Academic Press, 1978, pp. 721-732

51 Synder, M.H., Clements, M.L., DeBorde, D., Maassab, H.F. and Murphy, B.R. The acquisition of the PA polymerase and matrix protein genes of the influenza A Ann Arbor $/ 6 / 60$ coldadapted donor virus attenuates wild type influenza $A$ virus for humans. J. Clin. Med. 1985, in press

52 Davenport, F.M., Hennessy, A.V., Maassab, H.F., Minuse, E., Clark, L.C., Abrams, G.D. and Mitchell, J.R. Pilot studies on recombinant cold adapted live type $A$ and $B$ influenza virus vaccines. J. Infect Dis. 1977, 136, 17

53 La Montagne, J. R., Wright, P.R., Clements, M.L., Maassab, H.F. and Murphy, B.R. Prospects for live, attenuated influenza vaccines using reassortants derived from $A$ Ann Arbor $/ 6 / 60$ (H2N2) donor virus. In: The origin of pandemic influenza viruses (Ed. Laver, W.G.) Elsevier Science Publishing Co. Inc. Amsterdam, 1983

54 Clements, M.L., Betts, R.F. and Murphy, B. R. Advantage of live attenuated cold-adapted influenza $A$ virus over inactivated vaccine for $A \sim$ Washingtor $/ 80$ ( $H 3 N 2)$ wild-type virus infection. Lancet 1984, i, 705

55 Lazar, A, Okabe, N., Wright, P.F. Humoral and cellular immune responses of seronegative children vaccinated with a coldadapted influenza $\mathrm{A} / \mathrm{HK} / 23 / 77$ (H1 N1) recombinant virus. Infect Immun. 1980, 27,862

56 Wright, P.F., Okabe, N., McKee, K.T., Jr., Maassab, H.F. and Karzon, D.T. Cold-adapted recombinant influenza A virus vaccines in seronegative young children. J. Infect Dis. 1982. 146. 71

57 Maassab, H.F., Smitka, C.W., Donabedian, A.M., Monto, A.S., Cox, N.J. and Kendal, A.P. Characterization of influenza virus 'cold' recombinants derived at the non-permissive temperature $\left(38^{\circ} \mathrm{C}\right)$. Dev. Cell Biol. 1981, 7, 395

58 Maassab, H.F. Cox N.J. Murphy, B.R. and Kendal A.P Biological, genetic and biochemical characterization of a coldadapted recombinant $A \vee$ Victoria $/ 3 / 75$ virus and its evaluation in volunteers. Dev. Biol. Stand. 1977, 39, 25

59 Odagiri, T., Smitka, C.W. and Maassab, H.F. Cold-adapted reassortants of influenza A virus in MDCK cells. II. Role of the temperature-sensitive property of cold-adapted reassortants in mice. Microbiol. Immunol. 1983, 27, 203

60 Reference deleted

61 Moritz, A.J., Kunz, C., Hofmann, H., Reeve, I. and Maassab, H.F. Evaluation of a cold recombinant $A$ Victoria $/ 3 / 75$ virus in adult volunteers. J. Infect Dis. 1980, 142, 857

62 Cate, T.R. and Couch, R.B. Live A Victoria/75 (H3 N2) virus vaccine reactogenicity, immuogenicity and protection against wild-type challenge. Infect. Immun. 1982, 38, 141

63 Ghendon, Y.Z., Klimov, A.I., Alexandrova, G.I. and Polezhaev, F.I. Analysis of genome composition and reactogenicity of recombinants of cold adapted and virulent virus strains. $J$. Gen. Virol. 1981, 53, 215

64 Cox, N.J., Maassab, H. F. and Kendal, A.P. Comparative studies of wild-type and cold-mutant (temperature-sensitive) influenza viruses: Nonrandom reassortment of genes during preparation of live virus vaccine candidates by recombination at $25^{\circ} \mathrm{C}$ between recent $\mathrm{H} 3 \mathrm{~N} 2$ and $\mathrm{H} 1 \mathrm{~N} 1$ epidemic strains and coldadapted A Ann Arbor/1/60. Virology, 1979, 97, 190

65 Monto, A.S. Miller, F.D., and Maassab, H.F. Evaluation of an attenuated cold-recombinant influenza $B$ virus vaccine. $J$. Infect. Dis. 1982, 145, 57

66 Kitsak, V. Changes in the hereditary properties of sindbis virus in long-term cultivation under conditions of lowered temperature. Vopr. Virusol. 1970, 15, 177

67 Rohitayodhin, S. and Hammon, W. McD. Studies on Japanese $B$ encephalitis virus vaccines from tissue culture. I. Virus growth and survival at $30^{\circ} \mathrm{C} . \mathrm{J}$. Immunol. $1962,89,582$

68 Reference deleted

69 Reference deleted 
70 Wittmann, G. and Ahl, P. Genetische merkmale attenuierter maul-und-klauenseuche-virusstamme. Bull. Off. Int. Epizoot. 196461.579

71 Unantesev, N.M., Sergeev, V.A., Syusyukin, A.A and Trubitsyn, B.l. Attenuation of foot and mouth disease virus (variant Ai) in a cell culture. Dokl. Vses Akad. Sel'skokhoz Nauk Im Vi Lenina, 1968, 5. 35

72 Mirchamsky, H. and Taslimi, H. Some properties of avirulent cold variants of African horse sickness virus. Res. Vet. Sci. $1967,8,195$

73 Maassab, H.F. Development of variants of influenza virus. In: The biology of large RNA virus (Eds. Barry, R.D. and Mahy, B.W.J.) New York, Academic Press, 1970, pp. 542-566

74 Hozinski, V.I., Seibil, V. B., Pantelyeva, N.S., Mazurova, S. M. and Novikiva, E.A. The rct $/ 40$ and T/50 markers and the characteristics of some variants of measles virus. Acta. Virol. 1966, 10,20
75 Van Der Heide, L. Development of a day old chick vaccine against avian viral arthritis/tenosynovitis. J. Am. Vet. Med. Assoc. 1980, 177, 258

76 Yurlova, T.I., Lysov, V.V., Medvedeva, T.E., Selivanov, A.A and Smorodinstev. AA Genetic markers of clonal variants of adenovirus type 1. Vopr. Virusol. 1975, 18, 91

77 Fidzianska, E. Temperature mutants and recombinants of vaccinia virus: II. Recombination between temperature mutants. Acta. Virol. 1972, 16, 298

78 Alexandrova, G.l., Polezhaev, F.I., Budilovsky, G.N., Garmashova, L.M. Topuria, N.A., Egorov, AY., RomejkoGurko, Y.R., Koval, T.A, Lisovskaya, KV., Klimov, A.I. and Ghendon, Y.Z. Recombinant cold-adapted attenuated influenza A vaccines for use in children: Reactogenicity and antigenic activity of cold-adapted recombinants and analysis of isolates from the vaccinees. Infect Immun. 1984, 44, 734 